\title{
Ryanodine receptors: physiological function and deregulation in Alzheimer disease
}

\author{
Dolores Del Prete ${ }^{1,2,3}$, Frédéric Checler ${ }^{1,2^{*}}$ and Mounia Chami ${ }^{1,2^{*}}$
}

\begin{abstract}
Perturbed Endoplasmic Reticulum (ER) calcium $\left(\mathrm{Ca}^{2+}\right)$ homeostasis emerges as a central player in Alzheimer disease (AD). Accordingly, different studies have reported alterations of the expression and the function of Ryanodine Receptors (RyR) in human AD-affected brains, in cells expressing familial AD-linked mutations on the $\beta$ amyloid precursor protein (BAPP) and presenilins (the catalytic core in $\gamma$-secretase complexes cleaving the $\beta A P P$, thereby generating amyloid $\beta$ (AB) peptides), as well as in the brain of various transgenic AD mice models. Data converge to suggest that RyR expression and function alteration are associated to AD pathogenesis through the control of: i) $\beta A P P$ processing and A $\beta$ peptide production, ii) neuronal death; iii) synaptic function; and iv) memory and learning abilities. In this review, we document the network of evidences suggesting that RyR could play a complex dual "compensatory/protective versus pathogenic" role contributing to the setting of histopathological lesions and synaptic deficits that are associated with the disease stages. We also discuss the possible mechanisms underlying RyR expression and function alterations in AD. Finally, we review recent publications showing that drug-targeting blockade of RyR and genetic manipulation of RyR reduces $A \beta$ production, stabilizes synaptic transmission, and prevents learning and memory deficits in various AD mouse models. Chemically-designed RyR "modulators" could therefore be envisioned as new therapeutic compounds able to delay or block the progression of AD.
\end{abstract}

Keywords: Ryanodine receptor, Calcium, Alzheimer disease, Endoplasmic reticulum, Neurodegeneration, Presenilin, Amyloid precursor protein, Amyloid beta

\section{Introduction}

Alzheimer Disease (AD) is the most common type of dementia characterized clinically by progressive deterioration of cognitive functions including memory, reasoning, and language [1]. Neuropathological hallmarks of the disease include extracellular amyloid plaques mainly composed of a set of hydrophobic peptides referred to as $\beta$-amyloid peptides $(A \beta)$ aggregates and intracellular neurofibrillar tangles (NFT) composed of hyperphosphorylated microtubule-associated tau protein [2-4]. Aging is the major risk factor for the most common late-onset cases AD. However, a significant number of aggressive cases generally characterized by an earlier onset are inherited in an autosomal dominant manner (FAD) $[5,6]$, and caused by mutations on the $\beta$-Amyloid precursor protein ( $\beta$ APP, the precursor of the $A \beta$ peptides) [7] and on

\footnotetext{
*Correspondence: checler@ipmc.cnrs.fr; mchami@ipmc.cnrs.fr

${ }^{1}$ Université de Nice Sophia Antipolis, IPMC, Sophia Antipolis, Nice, F-06560 Valbonne, France

${ }^{2}$ CNRS, IPMC, Sophia Antipolis, Nice, F-06560 Valbonne, France

Full list of author information is available at the end of the article
}

presenilins (PS1 and PS2) (catalytic core components of the $\beta$ APP cleaving enzyme $\gamma$-secretase [2,3]) (Figure 1). Interestingly, both mutations in PS1-2 and $\beta$ APP proteins either modify the nature of $A \beta$ peptides and/or affect the levels of their production $[8,9]$.

Calcium $\left(\mathrm{Ca}^{2+}\right)$ is a ubiquitous signal transduction molecule. It plays a key role in the modulation of neuronal activity and is involved into a wide array of cellular signals regulating various critical processes, such as cell growth, differentiation, metabolism, exocytosis, and apoptosis [10]. In neurons, the elevation of cytosolic $\mathrm{Ca}^{2+}$ concentration $\left(\left[\mathrm{Ca}^{2+}\right]_{\mathrm{i}}\right)$ triggers the release of neurotransmitter at synaptic junctions and contributes to dendritic action potential, regulates the activity-dependent changes in gene expression, as well as synaptic plasticity [11]. Cytosolic $\mathrm{Ca}^{2+}$ levels are kept in a very low range $(\approx 100 \mathrm{nM})$ compared with the levels present in the extracellular space $(\approx 2 \mathrm{mM})$ or inside intracellular stores $(\approx 100-500 \mu \mathrm{M})$, where the endoplasmic reticulum (ER) represents the major dynamic $\mathrm{Ca}^{2+}$ intracellular pool [12]. Neuronal $\mathrm{Ca}^{2+}$ signaling implicates a 


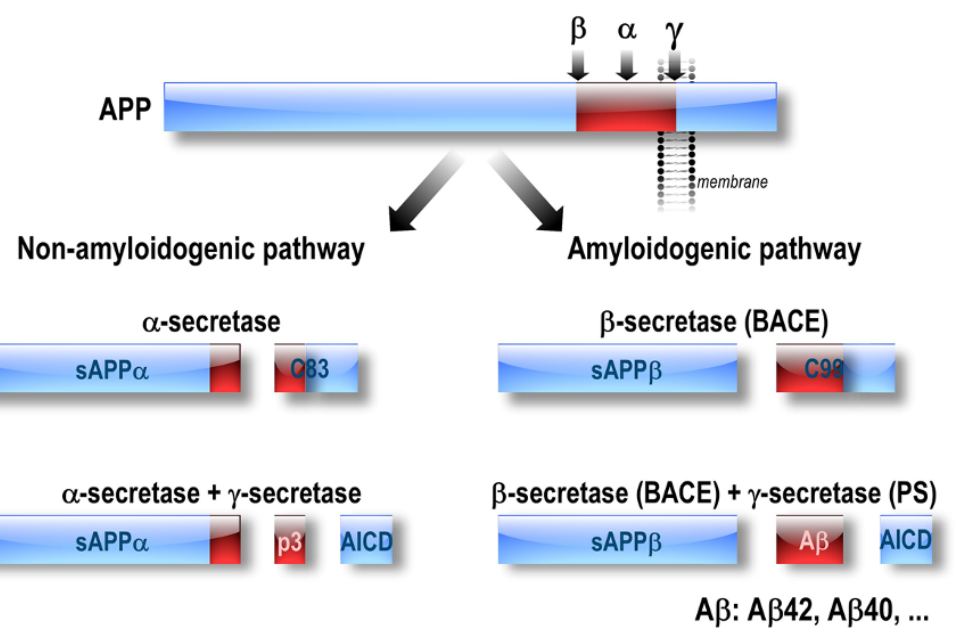

Figure 1 Amyloidogenic and non-amyloidogenic pathways of $\beta$ amyloid precursor protein ( $\beta A P P)$ processing. $A \beta$ peptides are derived from the processing of the $\beta$ APP through the amyloidogenic pathway, implicating $\beta$-secretase (BACE1) and $\gamma$-secretase complex (composed of PS1 or PS2, Nicastrin, anterior pharynx-defective-1 (APH-1), and presenilin enhancer-2 (PEN-2)). A $\beta$ production is abolished when $\beta A P P$ is processed through the non-amyloidogenic pathway implicating a-secretase and $\gamma$-secretase complexes.

complex interplay between $\mathrm{Ca}^{2+}$ entry through the plasma membrane and release from the ER (Figure 2). The ER is a continuous and highly motile network distributed throughout the neuron within dendrites and dendritic spines, axons and presynaptic nerve terminals, as well as in growth cones
[13] and supports diverse functions within each of these cellular compartments [14]. Thus, in dendrites, ER $\mathrm{Ca}^{2+}$ release is involved in modulating postsynaptic responses and synaptic plasticity [15]; in axon terminals, it is involved in vesicle fusion and neurotransmitter release [16]; in the

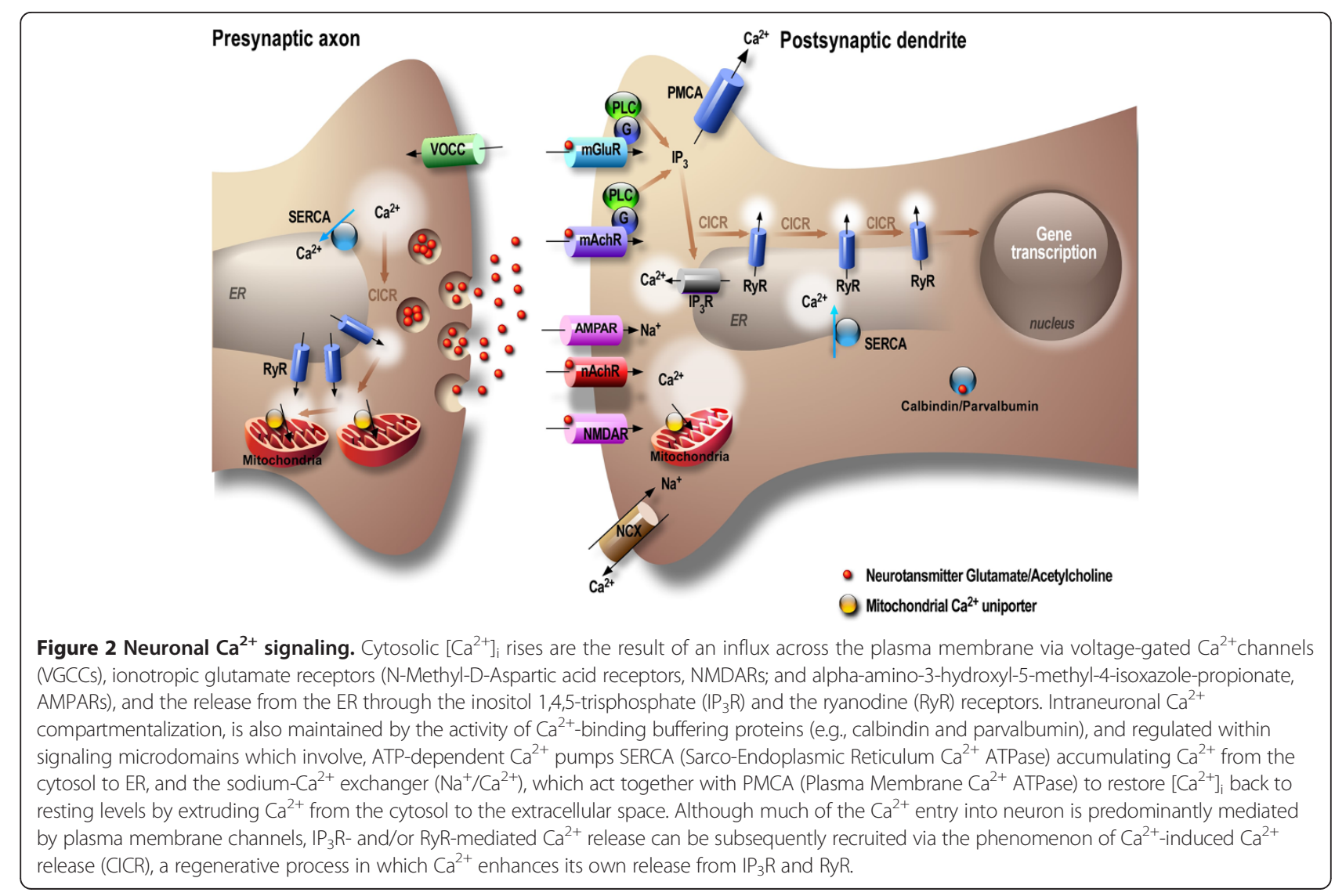


soma, it is coupled to the activation of $\mathrm{Ca}^{2+}$-sensitive signaling pathways such as kinase and phosphatase activities [11]; and in the perinuclear space, it can trigger gene transcription [17]. $\mathrm{Ca}^{2+}$ mobilization from the ER is also important in growth cone activity involved in the formation of new connections and/or the strengthening of preexisting connections that occur during learning and memory in the adult brain [18].

The hypothesis that $\mathrm{Ca}^{2+}$ homeostasis perturbation could play a pivotal role in cascading events to $\mathrm{AD}$ was introduced more than 20 years ago [19]. Data obtained from experiments on dissociated cells, brains slices, and more recently and importantly on live $\mathrm{AD}$ animal models confirmed this hypothesis [20-23]. Data are now converging to demonstrate the important role of ER $\mathrm{Ca}^{2+}$ deregulation in AD $[24,25]$. In this review, we will specifically highlight how primary alterations of the expression and function of the ryanodine receptor (RyR) $\mathrm{Ca}^{2+}$ channels may play a key role in the setting of histopathological lesions, alteration of synaptic plasticity, and learning and memory deficits that are associated with the late stages of the disease and how these receptors may interplay with secretases expression and function and $\beta$ APP catabolites.

\section{Review}

\section{RyRs expression and structure}

RyRs are a family of three known mammalian isoforms: RyR1, RyR2, and RyR3 which are classified as "skeketal muscle", "heart" and "brain" types, respectively with respect to their major tissue distribution although all isoforms can be found in the brain. Thus, RyR1 is expressed at low levels in cerebellum and Purkinje cells. RyR2 is predominantly expressed in Purkinje cells of cerebellum and cerebral cortex, and in dentate gyrus of the hippocampus. RyR3 has been detected in hippocampal CA1 pyramidal cell layer, the basal ganglia, and olfactory bulbs [26].

RyRs are homotetramers with a total molecular mass of about $2 \mathrm{MDa}$. Each subunit of the receptor is a compound with a molecular mass of about $565 \mathrm{kDa}$, with the $4 / 5$ of the channel comprising an huge $\mathrm{N}$-terminal cytoplasmic domain that serves as a scaffold for channel regulators while the remaining domain is in the ER lumen [27].

\section{RyRs pharmacology and regulation}

$\mathrm{Ca}^{2+}$ activates all RyRs at low nanomolar concentrations with RyR1 > RyR2 > RyR3 in term of sensitivity to cytosolic free $\left[\mathrm{Ca}^{2+}\right][28,29]$. Caffeine and ryanodine are pharmacological modulators of RyRs. Caffeine freely diffuses through the plasma membrane and subsequent cell excitation can be directly monitored by its ability to quench the fluorescence of various $\mathrm{Ca}^{2+}$ sensors in a wavelengthindependent manner [30]. All structures of neurons, from soma to dendrites and presynaptic terminals, respond to caffeine. Caffeine induces a $\left[\mathrm{Ca}^{2+}\right]_{i}$ rise without a requi rement for extracellular $\mathrm{Ca}^{2+}$, and the $\left[\mathrm{Ca}^{2+}\right]_{\mathrm{i}}$ elevation is not associated with plasmalemmal $\mathrm{Ca}^{2+}$ movements. Caffeine-evoked $\left[\mathrm{Ca}^{2+}\right]_{\mathrm{i}}$ elevations are sensitive to phar macological modulators interacting with RyRs or with SERCA pumps. Thus, these $\left[\mathrm{Ca}^{2+}\right]_{\mathrm{i}}$ responses are blocked by ryanodine, ruthenium red, and procaine and disappear after inhibition of SERCA-dependent ER $\mathrm{Ca}^{2+}$ uptake with thapsigargin (TG) or cyclopiazonic acid (CPA) [30]. Caffeine-induced $\mathrm{Ca}^{2+}$ release that is sensitive to TG and ryanodine has even been observed in individual spines of cultured hippocampal neurons, which are rich in RyR [31]. Ryanodine locks the RyR channel to an "open state" at low concentrations $(<10 \mathrm{nM})$ and to "closed state" at higher concentrations $(>100 \mu \mathrm{M})$ [32]. The activity of RyRs is also inhibited by $\mathrm{mM}$ concentrations of $\mathrm{Mg}^{2+}$ and $\mu \mathrm{M}$ concentrations of ruthenium red [32-34]. Dantrolene is well known inhibitor of RyRs. It was first characterized as a skeletal muscle relaxant [35], and is widely used in anesthesiology practice and in treating malignant hyperthermia $(\mathrm{MH})$ [36]. Dantrolene was described to be bind to amino acids 590-609 of RyR1 isoform, which presumably stabilizes the channel protein, thus providing evidence for a direct action of dantrolene on RyRs [37,38]. This stabilizing effect inhibits aberrant activation of the channel and prevents excessive $\mathrm{Ca}^{2+}$ release from intracellular stores. Different papers also tend to show that dantrolene binds to the corresponding sequence (amino acids 601-620) of RyR2 [39,40]. Recent evidence has suggested that dantrolene may ameliorate abnormal RyR2mediated $\mathrm{Ca}^{2+}$ release associated with heart failure [41-43]. It is worth to mention that the specificity of dantrolene towards RYRs has been debated in a recent review [23], since azumolene, an equipotent dantrolene analog, inhibits a component of SOCE coupled to activation of RyR1 by caffeine and ryanodine $[23,44]$.

RyRs are also directly or indirectly modulated by other channels and kinases [45]. Calmodulin (CaM), a $17 \mathrm{kDa}$ $\mathrm{Ca}^{2+}$ binding protein, binds to RyR1 at Cys3635 and to the corresponding region on RyR2, 3578-3603. CaM can either activate or inhibit RyR1 depending on $\mathrm{Ca}^{2+}$ concentrations but appears to preferentially inhibit RyR2 [45,46]. The 12 and $12.6 \mathrm{kDa}$ FK506 binding proteins (FKBP12 and FKBP12.6) known also as Calstabin1 and Calstabin2 bind to, and stabilize the closed state of RyR1 and RyR2, respectively, and are essential for coupled gating of RyR channels [47]. $\mathrm{Ca}^{2+} /$ calmodulin-dependent protein kinase II (CaMKII) associates with, phosphorylates, and regulates the activity of RyR in the heart and skeletal muscle [48]. RyRs may also be regulated by Sorcin, a cytosolic $\mathrm{Ca}^{2+}$-binding protein [49], and by Calsequestrin (CSQ), a low affinity, high capacity luminal $\mathrm{Ca}^{2+}$ buffering protein [50]. Different studies reported that mutations in RyR or alterations in the post-translational modifications of RyRs (i.e. hyper-phosphorylation, -oxidation, 
and -nitrosylation) can shift RyRs from a finely regulated state to an unregulated $\mathrm{Ca}^{2+}$ leak channel. RyR "leaky" channels alter cell physiology and are associated with different pathological states in muscle and nonmuscle cells [51-55].

\section{Overview of $\mathrm{Ca}^{2+}$ dysregulation in $\mathrm{AD}$}

Alteration of $\mathrm{Ca}^{2+}$ signals in $\mathrm{AD}$ were largely linked to the "amyloid hypothesis" where the modification of the nature, levels, biophysical properties and subcellular localization of $\mathrm{A} \beta$ peptides in various areas of the brain is believed to contribute to a molecular dysfunction culminating in neuronal death and dementia. A large number of studies also revealed the potent implication of PS as major contributor to $\mathrm{Ca}^{2+}$ deregulation in AD. The data listed below summarize the major findings obtained in this field:

I. In vivo imaging of $\mathrm{Ca}^{2+}$ transients in APP/PS1 $\left(\mathrm{APP}_{\text {swe }} / \mathrm{PS} 1-\triangle \mathrm{E} 9\right)$ mice model revealed that about $20 \%$ of transgenic mice dendrites and axons harbor moderate to severe $\left[\mathrm{Ca}^{2+}\right]$ elevation than wild type mice, and that the severity of $\mathrm{Ca}^{2+}$ overload correlates with the structural integrity of the dendrite or axon. It was suggested that $\left[\mathrm{Ca}^{2+}\right]$ elevation may depend on the $A \beta$ accumulation since $\mathrm{Ca}^{2+}$ transients were not observed in animals without cortical plaques (i.e. young $\mathrm{APP}_{\text {swe }}$ and PS1 mutant mice) [56]. Another group reported a more complex alteration of $\mathrm{Ca}^{2+}$ transients in a different $\mathrm{AD}$ mice model $\left(\mathrm{APP}_{\text {swe }} / \mathrm{PS}_{\mathrm{G} 384 \mathrm{~A}}\right)$ by showing a spatial distribution of silent neurons (decreased $\mathrm{Ca}^{2+}$ signals) (29\%) and hyperactive neurons (increased $\mathrm{Ca}^{2+}$ signals) (21\%) in transgenic mice brain as compared to wild type mice brain. In accordance with the paper by Kuchibhotla et al., they also proposed that the neurons hyperactivity occur near A $\beta$ plaques [57].

II. Exogenous application of synthetic $A \beta$ peptides or oligomeric agregates leads to elevated levels of $\left[\mathrm{Ca}^{2+}\right]_{\mathrm{i}}$ $[58,59]$. A $\beta$-mediated changes in $\left[\mathrm{Ca}^{2+}\right]_{i}$ occur likely through $A \beta$ ion channels incorporation in the cell membrane, changes in membrane permeability, and phosphatidylserine asymmetry $[60,61]$. Actually, in addition to promoting influx of extracellular $\mathrm{Ca}^{2+}$ [62], $\mathrm{A} \beta$ oligomers potently evokes $\mathrm{Ca}^{2+}$ signals through its release from the ER [58,63-65]. Another mechanism underlying $\mathrm{A} \beta$-mediated elevated $\mathrm{Ca}^{2+}$ entry was recently revealed by renner et al. showing that soluble $A \beta$ oligomers accumulation at the synapse recruited mGluR5 thus elevating intracellular $\mathrm{Ca}^{2+}$ [66]. It is important to emphasize that the level of exogenously applied $A \beta$, used in these studies, is orders of magnitude above physiological levels. Thus, the relevance of $\mathrm{A} \beta$-mediated $\mathrm{Ca}^{2+}$ signaling deregulation is provided in experiments using in vitro and in vivo AD models overproducing endogenously $\mathrm{A} \beta$ (see details in item IV).

III. Mutations of PS1 and PS2 had a significant impact on $\mathrm{Ca}^{2+}$ signaling in AD models. Actually, PS may directly alter ER $\mathrm{Ca}^{2+}$ signaling and affect activity and/or expression of many proteins involved in ER $\mathrm{Ca}^{2+}$ signaling deregulation in AD. Several studies showed that PS mutations induce exacerbated $\mathrm{IP}_{3} \mathrm{R}$ - and RyR- mediated $\mathrm{Ca}^{2+}$ release [67-72], and alter the function of the SERCA pump [73]. This has been documented in fibroblasts isolated from FAD patients, in cellular systems expressing wild type and mutated PS and in hippocampal and cortical neurons of AD mice $[67,68,70-72]$. PS were also shown to support ER $\mathrm{Ca}^{2+}$ leakage $[74,75]$, likely through their function as low conductance, passive $\mathrm{ER} \mathrm{Ca}^{2+}$ leak channels, independently of their $\gamma$-secretase activity [74,76-79]. Even if PS-mediated ER Ca ${ }^{2+}$ leak was recently debated $[80,81]$, recent data obtained by other laboratories and using different systems tend now to confirm the leak function of PS $[82,83]$.

IV. Other studies have identified $\beta A P P$-mediated changes to $\mathrm{ER} \mathrm{Ca}^{2+}$ signaling related to Amyloidogenic processing of $\beta$ APP. Decreased production of sAPP $\alpha$ (soluble APP $\alpha$ fragment: derived from nonamyloidogenec processing of $\beta \mathrm{APP}$ ) (Figure 1), was shown to activate $\mathrm{K}^{+}$channels [84]. The transcription regulatory factor AICD (APP intra-cellular domain: derived from both amyloidogenic and nonamyloidogenic $\beta$ APP processing) (Figure 1) may affects $\mathrm{Ca}^{2+}$ hormeostasis by regulating the expression of genes involved in $\mathrm{Ca}^{2+}$ homeostasis [85-87], namely the transient receptor potential cation channel subfamily C member 5 (TRPC5), a component of receptor-activated nonselective $\mathrm{Ca}^{2+}$ permeant cation channel [88]. Additional studies support the physiological role of $\beta$ APP in $\mathrm{Ca}^{2+}$ homeostasis by demonstrating that $\beta A P P$ downregulation enhances both $\mathrm{Ca}^{2+}$ content of the ER and acidic stores and the dynamics of store operated $\mathrm{Ca}^{2+}$ channel activity [89]. As for PS, $\beta A P P$ FAD mutations were also shown to alter $\mathrm{Ca}^{2+}$ signals. It has been documented that fibroblasts from $\mathrm{AD}$ patients harboring the Swedish double mutation $\left(\beta A P P_{\text {swe }}: \beta A P P_{K 670 N / M 671 L}\right)$ showed reduced bombesin-induced intracellular $\mathrm{Ca}^{2+}$ elevations compared to controls while all other pools of $\mathrm{Ca}^{2+}$ were unaffected [90]. Primary cortical neurons from TgCRND8 mice carrying combined $\beta A P P_{\text {swe }}$ and Indiana $\left(\beta A P P_{V 717 F}\right)$ mutations show elevated ER release of $\mathrm{Ca}^{2+}$ [91]. In accordance with these findings, we recently reported a global alteration of $\mathrm{Ca}^{2+}$ homeostasis in human neuroblastoma SH-SY5Y cells overexpressing human wild type $\beta \mathrm{APP}$ or $\beta \mathrm{APP}$ swe 
This $\mathrm{Ca}^{2+}$ alteration is manifested by an increase in cytosolic $\mathrm{Ca}^{2+}$ signals associated to enhanced $\mathrm{ER} \mathrm{Ca}^{2+}$ passive leakage, and large $\mathrm{IP}_{3} \mathrm{R}$ - and RyR-mediated $\mathrm{Ca}^{2+}$ release as compared to control cells, and to increased VGCC permeability to $\mathrm{Ca}^{2+}$ [92].

\section{A focus on Ryanodine Receptors-mediated $\mathrm{Ca}^{2+}$ signals deregulation in $A D$}

Several studies addressed the role of RyR-mediated $\mathrm{Ca}^{2+}$ disruptions in $\mathrm{AD}$ models (Table 1). It was shown that the RyR blocker dantrolene reversed carbachol-induced elevation of $\mathrm{Ca}^{2+}$ release in human neuroblastoma SH-SY5Y cells expressing PS1 mutants ( $\mathrm{PS}_{\mathrm{M} 146 \mathrm{~V}}$, and $\mathrm{PS}_{\mathrm{L} 250 \mathrm{~S}}$ ) [93]. Accordingly, it was also reported that the RyR agonist caffeine evoked larger $\mathrm{Ca}^{2+}$ liberation in primary cultured neurons derived from the triple transgenic mice model 3xTg-AD (knock in for the mutated PS1 $1_{\mathrm{M} 146 \mathrm{~V}}$, and overexpressing mutated $\beta$ APP and microtubule-associated tau protein $\left(\mathrm{PS}_{\mathrm{M} 146 \mathrm{~V}} / \mathrm{APP}_{\text {swe }} /\right.$ tau $\left.\left._{\mathrm{P} 30 \mathrm{IL}}\right)\right)$, and the transgenic knock in mice model expressing mutated PS1 $\left(\mathrm{PS1}_{\mathrm{M} 146 \mathrm{~V}}\right)$ [94]. Increased RyR channel function was further confirmed in PC12 cells expressing wild type PS1, $\mathrm{PS}_{\mathrm{L} 286 \mathrm{~V}}, \mathrm{PS}_{\mathrm{M} 146 \mathrm{~V}}$ or $\mathrm{PS} 2_{\mathrm{N} 141 \mathrm{~L}}$ mutants $[95,96]$. Interestingly, RyR-mediated ER $\mathrm{Ca}^{2+}$ homeostasis deregulation in $A D$ was supported by the finding showing that exacerbated

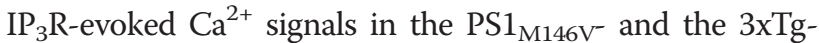
AD-derived neurons occur through increased RyRmediated $\mathrm{CICR}\left(\mathrm{Ca}^{2+}\right.$-induced $\mathrm{Ca}^{2+}$ release) (Figure 2) [72]. Studies by the group of Bezprozvanny postulated that the large RyR-mediated $\mathrm{Ca}^{2+}$ release observed in the $3 x \mathrm{Tg}$ $\mathrm{AD}$-derived neurons is likely associated to the impairment of PS $\mathrm{Ca}^{2+}$ leak channel function and to increased ER $\mathrm{Ca}^{2+}$ pool [78]. The emerging hypothesis form these studies is that RyR function alteration may be intimately linked to PS. However, experiments using the PScDKO mice model (PS1 and PS2 conditioned double knockout mice) lead to controversial conclusions [78,97]. While the group of Bezprozvanny showed that primary neurons derived from PSCDKO mice harbor increased ER $\mathrm{Ca}^{2+}$ pool and increased RyR-mediated $\mathrm{Ca}^{2+}$ signals [78], a recent study by $\mathrm{Wu}$ et al. showed that neurons derived from the same study model did not harbor alteration in $\mathrm{ER} \mathrm{Ca}^{2+}$ content and rather display reduced RyR agonist-induced $\mathrm{Ca}^{2+}$ release from the ER and RyR-mediated synaptic responses [97]. Furthermore, the authors demonstrated that knockdown of RyR expression in wild-type hippocampal neurons mimics the defects observed for $\mathrm{Ca}^{2+}$ homeostasis and presynaptic function in PScDKO neurons [97]. These data further support previous results demonstrating a physiological role of PS in synaptic plasticity $[98,99]$, and that inhibition

Table 1 RyR-mediated calcium deregulation in AD

\begin{tabular}{|c|c|c|c|}
\hline AD models & Study systems & RyR-mediated $\left[\mathrm{Ca}^{2+}\right]$ dysregulations & References \\
\hline$P S 1_{M 146 V}$ and PS1 L250S & SH-SY5Y cells & Dantrolene blocked $\uparrow$ carbachol-induced $\left[\mathrm{Ca}^{2+}\right]$ signals (vs. wild type PS1) & {$[93]$} \\
\hline $\begin{array}{l}\text { 3xTgAD mice } P S 1_{M 146 V} \\
\text { KI Tg mice }\end{array}$ & Primary cortical neurons & $\uparrow$ caffeine-induced $\left[\mathrm{Ca}^{2+}\right]$ signals (vs. wt neurons) & [94] \\
\hline $\begin{array}{l}\text { PS1 } 1_{W T}, P S 1_{L 286 V}, P S 1 \\
\text { M146V, PS2 N141L }\end{array}$ & PC12 cells & $\uparrow$ caffeine-induced $\left[\mathrm{Ca}^{2+}\right]$ signals (vs. vector transfected cells) & {$[95,96]$} \\
\hline $\mathrm{APP}_{\text {wt }}$ and $\mathrm{APP}_{\text {swe }}$ & SH-SY5Y cells & $\uparrow$ caffeine-induced $\left[\mathrm{Ca}^{2+}\right]$ signals (vs. vector transfected cells) & [92] \\
\hline Tg2576 mice & hippocampal primary neurons & $\uparrow$ caffeine-induced $\left[\mathrm{Ca}^{2+}\right]$ signals (vs. wt neurons) & [92] \\
\hline \multirow{2}{*}{$\begin{array}{l}\text { PS } \mathrm{M}_{146 \mathrm{~V}} \mathrm{KI} \mathrm{Tg} \text { and } \\
3 \times \mathrm{TgAD} \text { mice }\end{array}$} & \multirow{2}{*}{$\begin{array}{l}\text { Acute brain slice preparation ( } 6 \mathrm{~W}, \\
6 \mathrm{mo} \text { and } 1.5 \mathrm{Y})\left(^{*}\right)\end{array}$} & $\uparrow$ caffeine-induced $\left[\mathrm{Ca}^{2+}\right]$ signals & \multirow[t]{2}{*}[72,100]{} \\
\hline & & $\begin{array}{l}\text { Dantrolene reduced the } \mathrm{IP}_{3} \text {-evoked } \mathrm{Ca}^{2+} \text { responses (vs. wt-derived brain } \\
\text { slices) }\end{array}$ & \\
\hline $\begin{array}{l}\text { Extracellular A } \mathrm{\beta} 42 \\
\text { application }\end{array}$ & Primary Cortical neurons & $\begin{array}{l}\text { siRyR-3 blocked increased ryanodine- and glutamate-induced }\left[\mathrm{Ca}^{2+}\right] \\
\text { signals upon A } 42 \text { application (vs. A } 42 \text { non-treated neurons) }\end{array}$ & [91] \\
\hline \multirow{2}{*}{$\begin{array}{l}\text { PSCDKO Tg and } 3 \times \operatorname{TgAD} \\
\text { mice }\end{array}$} & \multirow[t]{2}{*}{ Primary hippocampal neurons } & $\uparrow$ caffeine-induced $\left[\mathrm{Ca}^{2+}\right]$ signals (vs. wt-Tg neurons) & \multirow[t]{2}{*}[78]{} \\
\hline & & $\uparrow \mathrm{ER} \mathrm{Ca}^{2+}$ pool (vs. wt-Tg neurons) & \\
\hline \multirow[t]{2}{*}{ PSCDKO Tg mice } & \multirow[t]{2}{*}{ Primary hippocampal neurons } & $\leftrightarrow \mathrm{ER} \mathrm{Ca}^{2+}$ pool & \multirow[t]{2}{*}{ [97] } \\
\hline & & $\downarrow$ caffeine-induced $\left[\mathrm{Ca}^{2+}\right]$ signals (vs. wt neurons) & \\
\hline \multirow{3}{*}{$\begin{array}{l}\mathrm{PS}_{\mathrm{N} 141 \mathrm{~L}} \mathrm{Tg} \text { and } \\
\mathrm{PS}_{\mathrm{N} 141 \mathrm{~L}} / \mathrm{APP}_{\text {swe }} \text { mice }\end{array}$} & \multirow{3}{*}{$\begin{array}{l}\text { Primary neuronal cultures and } \\
\text { acute brain slice preparation }\end{array}$} & $\downarrow \mathrm{ER}\left[\mathrm{Ca}^{2+}\right]$ & \multirow[t]{3}{*}{ [101] } \\
\hline & & $\downarrow \mathrm{PP}_{3}$-generating $\mathrm{Ca}^{2+}$ responses & \\
\hline & & $\uparrow$ caffeine-induced $\left[\mathrm{Ca}^{2+}\right]$ signals (vs. wt-Tg neurons) & \\
\hline \multirow{2}{*}{$\begin{array}{l}\mathrm{PS} 1_{\mathrm{M} 146 \mathrm{~V}} \mathrm{Kl} \mathrm{Tg} \text { and } \\
\mathrm{PS1} 1_{\mathrm{M} 146 \mathrm{~V}} / \mathrm{APP}_{\text {swe }} \mathrm{Tg} \\
\text { mice }\end{array}$} & \multirow[t]{2}{*}{ Acute brain slice preparation } & $\uparrow$ caffeine-induced $[\mathrm{Ca} 2+]$ signals & \multirow[t]{2}{*}{ [102] } \\
\hline & & RyR blockade prevents NMDA Ca ${ }^{2+}$ response (vs. wt-derived brain slices) & \\
\hline
\end{tabular}

Abbreviations: $\left[\mathrm{Ca}^{2+}\right]$ calcium signals are depicted as $\uparrow$ (increased), $\downarrow$ (reduced), or $\leftrightarrow$ (unchanged) as compared to respective controls, (*) study was performed on acute brain slice preparation isolated from transgenic mice at different ages (6 weeks (W), 6 months (mo) and 1.5 years (Y), vs versus, Kl knock in, $T g$ Transgenic, wt Wild type, PScKO Tg mice are conditionally double knock out for PS1 and PS2, Tg2576 mice express the BAPP harboring Swedish double mutation $\left(A P P_{K 670 N} / M 671 L\right)$, 3XTgAD mice are generated from the PS1 $1_{M 146 V} \mathrm{KI}$ mouse overexpressing $\mathrm{APP}_{\text {swe }}$ and $\mathrm{Tau}_{\mathrm{P} 130 \mathrm{~L}}$. 
of RyR function mimics and occludes the effects of PS inactivation and intracellular $\mathrm{Ca}^{2+}$ homeostasis and synaptic dysfunction [99].

These studies may outline a possible regulation between RyR and PS towards ER $\mathrm{Ca}^{2+}$ homeostasis. However, the mechanisms underlying this regulation are still unraveled and the basis of the contradictory results in PSDKO cells is not clear.

Another question emerging in "AD $\mathrm{Ca}^{2+}$ hypothesis" is the real impact of PSs versus PSs-mediated $\beta A P P$ processing and $\mathrm{A} \beta$ peptides production in $\mathrm{Ca}^{2+}$ disturbances in AD models. To answer this question, in a recent study, Kipanyula and colleagues used two transgenic mice models carrying the FAD-linked $\mathrm{PS} 2_{\mathrm{N} 141 \mathrm{~L}}$ mutation either alone or in the presence of $\mathrm{BAPP}_{\text {swe }}$ mutation (PS2-APP) [101]. They reported in both $\mathrm{PS} 2_{\mathrm{N} 141 \mathrm{~L}}$ and PS2-APP transgenic neurons a similar reduction in $\mathrm{ER} \mathrm{Ca}^{2+}$ content and decreased response to $\mathrm{IP}_{3}$-generating agonists, albeit increased $\mathrm{Ca}^{2+}$ release induced by caffeine and increased $\mathrm{Ca}^{2+}$ excitability. Further experiments lead authors to postulate that enhanced response to caffeine in both models resulted from the increased level of RyRs observed in brains and cultured neurons derived from both transgenic mice as compared to wild-type mice [101]. The comparative analyses of both transgenic mice models lead authors to hypothesize that $\mathrm{Ca}^{2+}$ stores deregulation depend directly on the mutant PS2 itself and not on PS2-dependent APP processing or total $A \beta$ levels (i.e. larger $A \beta$ level was detected in PS2-APP mice as compared to PS2 mice) [101]. However, it may be argued that the A $\beta$ increase observed in PS2 transgenic mice models may be sufficient to cause the $\mathrm{Ca}^{2+}$ alterations and that the additional larger $\mathrm{A} \beta$ rise observed in the PS2-APP mice have no additional effect. In this scenario, RyR dysfunction in PS2 and PS2APP mice may also likely and predominantly dependent on a direct interaction of PS2 mutant with RyR.

Importantly, the real impact of $A \beta$ and of $\beta A P P$ overexpression and mutation on ER $\mathrm{Ca}^{2+}$ signaling and particularly on RyR dysfunction was revealed in AD-related study models independently from PS mutation or overexpression $[64,86,91,92,103,104]$. Regarding $\beta$ APP overexpression and mutation, it has been documented that primary cortical neurons isolated from TgCRND8 mice (described above) display elevated RyR-mediated $\mathrm{Ca}^{2+}$ release, while global $\mathrm{Ca}^{2+}$ handling remained unaffected [91]. Accordingly, we recently highlighted a fundamental role of increased RyRinduced $\mathrm{Ca}^{2+}$ release in SH-SY5Y neuroblastoma cell line stably overexpressing either wild-type or mutated human $\beta A P P\left(\mathrm{APP}_{695}\right.$ or $\mathrm{APP}_{\text {swe }}$ respectively), and in primary neu-

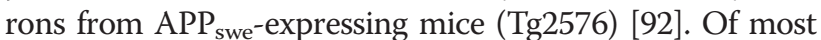
interest, it was also reported that exogenous $\mathrm{A} \beta$ oligomers may stimulate RyR-mediated $\mathrm{Ca}^{2+}$ release in wild type hippocampal neurons [105], and that application of soluble $\mathrm{A} \beta$ caused a marked increase in RyR activity, resulting in a 10-fold increase in channel open probability which was blocked by RyR antagonist ruthenium red [106].

\section{Ryanodine Receptors expression in AD}

The alteration of RyR expression in AD-affected brains was first described in 1999 by Kelliher et al. [107], who showed that $\left[{ }^{3} \mathrm{H}\right]$ ryanodine binding (indicative of RyR expression protein) is elevated in hippocampal regions (subiculum, CA2 and CA1) of human post-mortem tissue at early stages of the disease, i.e. prior to extensive neurodegeneration and overt A $\beta$ plaque deposition [107]. Recently another paper reported elevated RyR2 mRNAs levels early in mild cognitive impairment derived brains [108]. Accordingly, altered RyR2 expression was recently reported in a preliminary study of the whole-genome expression profile of sporadic and monogenic early-onset AD [109] (Table 2).

Interestingly, alteration of RyR expression was reported in different $\mathrm{AD}$ study models and was shown to be linked to $A \beta$ and/or overexpression of PS mutants. Thus, increased expression of RyR3 but not RyR1 or RyR2 was observed in cortical neurons isolated from C57Bl6 mice upon extracellular A 342 application [91], and in cortical neurons and brain tissue from TgCRND8 mice [91]. We recently showed that RyR protein and mRNAs levels are increased in neuroblastoma SH-SY5Y cells overexpressing wild type $\beta \mathrm{APP}$ or $\beta \mathrm{APP}_{\text {swe }}$ and in Tg2576 mice as compared to respective control mice [92] (Table 2).

Increased RyR expression was also largely reported in AD models where PS is overexpressed or mutated. Elevated RyR mRNAs and protein was first reported in in vitro models expressing PS1 mutants [95]. Importantly, RyR expression increases throughout the lifetime of the $\mathrm{PS} 1_{\mathrm{M} 146 \mathrm{~V}}$, and the 3xTg-AD transgenic mice [72,94,100]. Recent findings of Liu et al. further support these observations by showing increased expression of both RyR2 and RyR3 in $\mathrm{APP}_{\text {swe }} \mathrm{PS}_{\mathrm{L} 166 \mathrm{P}}$ transgenic mice [111]. It was proposed that the induction of RyR expression is a compensatory event linked to the loss of PS leak function [78]. This hypothesis was recently debated in a study using PSDKO mice model, where authors revealed that the absence of PS, on the contrary, triggers an hippocampal reduction of RyR protein levels [97]. The basis of the contradictory results about RyR expression in AD models may be linked to a variable regulation of RYR along AD pathology development and between brain areas. As a matter of fact, reduction of RyR2 and RyR3 mRNA levels and RyR2 protein expression was observed upon treatment with sublethal concentrations of A $\beta$ oligomers [112]. Kelliher, M. et al. [107] also reported a complex regulation of RyR expression in human $\mathrm{AD}$ brains where RyR expression was shown to be elevated in hippocampal regions in cases with early neurofibrillary pathology and reduced in the subiculum, and CA1-CA4 regions of the late stages [107] (Table 2). 
Table 2 RyR expression in Alzheimer disease

\begin{tabular}{|c|c|c|c|c|}
\hline AD samples/models & Brain regions/study systems & AD stage $(*)$ & RyR expression $(* *)$ & References \\
\hline Human AD post-mortem brains & Hippocampal regions (Subiculum, CA1, CA2) & Early stages (I-II) & $\uparrow\left[^{3} \mathrm{H}\right]$ RyR binding & {$[107]$} \\
\hline Human AD post-mortem brains & $\begin{array}{l}\text { Hippocampal regions (Subiculum, CA1, CA2, } \\
\text { CA3, and CA4) }\end{array}$ & Late stages $(\mathrm{V}-\mathrm{Vl})$ & $\begin{array}{l}\leftrightarrow\left[^{3} \mathrm{H}\right] \text { RyR binding } \\
\downarrow \text { RyR2 mRNA }\end{array}$ & [107] \\
\hline PS1 L285V, PS1 M146V mutations & PC12 cells & & $\uparrow$ RyR3 mRNA and protein & [95] \\
\hline$P S 1_{\text {M146V }} \mathrm{Kl}$ Tg mice & Primary neurons & & & \\
\hline Human AD post-mortem brains & mid frontal cortex & & $\downarrow$ RyR2-3 mRNA splice variants & [108] \\
\hline \multirow[t]{3}{*}{$\mathrm{MCl}$ post-mortem brains } & mid temporal and mid frontal cortex & & $\uparrow R y R 2$ mRNA; $\leftrightarrow$ RyR3 mRNA & \multirow[t]{3}{*}{ [108] } \\
\hline & mid frontal cortex & & $\downarrow$ RyR2 mRNA splice variant; & \\
\hline & mid temporal cortex & & $\uparrow$ RyR2 mRNA splice variant & \\
\hline \multirow[t]{2}{*}{ Extracellular Aß42 application } & \multirow[t]{2}{*}{ Primary cortical neurons } & & 个RyR3 mRNA; & \multirow[t]{2}{*}{ [91] } \\
\hline & & & $\leftrightarrow$ RyR1-2 mRNA & \\
\hline \multirow[t]{2}{*}{ CRDN8 Tg mice } & Primary cortical neurons & $4-4.5(\mathrm{mo})$ & $\uparrow R y R 3$ mRNA & \multirow[t]{2}{*}{ [91] } \\
\hline & Whole brains & & $\uparrow$ RyR3 protein & \\
\hline $3 x \operatorname{TgAD}$ mice & Primary hippocampal neurons & & $\uparrow$ RyR protein & [78] \\
\hline \multirow[t]{3}{*}{$\mathrm{PS}_{\mathrm{M} 146 \mathrm{~V}} \mathrm{Kl} \mathrm{Tg}$ mice $3 \times \mathrm{TgAD}$ mice } & \multirow[t]{3}{*}{ Whole brains } & $6(w)$ & $\uparrow$ RyR protein & \multirow[t]{3}{*}[72,110]{} \\
\hline & & $6(\mathrm{mo})$ & $\leftrightarrow$ RyR protein & \\
\hline & & $1.5(Y)$ & $\uparrow$ RyR protein & \\
\hline \multirow[t]{2}{*}{$3 \times \operatorname{TgAD}$ mice } & \multirow[t]{2}{*}{ Hippocampus } & \multirow[t]{2}{*}{$6-8(w)$} & 个RyR2 mRNA; & \multirow[t]{2}{*}[94,100]{} \\
\hline & & & $\leftrightarrow$ RyR1-3 mRNA & \\
\hline \multirow[t]{3}{*}{ Tg2576 mice } & \multirow[t]{3}{*}{ Cortex } & \multirow[t]{3}{*}{ 15-18 (mo) } & 个RyR2 mRNA; & \multirow[t]{3}{*}{ [92] } \\
\hline & & & $\leftrightarrow$ RyR1-3 mRNA & \\
\hline & & & $\uparrow$ RyR proteins & \\
\hline \multirow[t]{2}{*}{$\mathrm{APP}_{\mathrm{Wt}}$ and $\mathrm{APP}_{\text {swe }}$ mutation } & \multirow[t]{2}{*}{ SH-SY5Y cells } & & $\uparrow R y R 1-2-3$ mRNA & \multirow[t]{2}{*}{ [92] } \\
\hline & & & $\uparrow$ RyR proteins & \\
\hline \multirow[t]{3}{*}{ PScDKO Tg mice } & \multirow[t]{3}{*}{ Hippocampus } & \multirow[t]{3}{*}{$2(\mathrm{mo})$} & $\downarrow$ RyR proteins & \multirow[t]{3}{*}{ [97] } \\
\hline & & & $\downarrow\left[{ }^{3} \mathrm{H}\right]$ RyR binding & \\
\hline & & & $\leftrightarrow$ RyR mRNA & \\
\hline \multirow[t]{2}{*}{ Subletal $A \beta$ oligomers } & \multirow[t]{2}{*}{ Primary hippocampal neurons } & & $\downarrow$ RyR 2-3 mRNA & \multirow[t]{2}{*}{ [105] } \\
\hline & & & $\downarrow$ RyR 2 protein & \\
\hline $\mathrm{APP}_{\text {swe }} \mathrm{PS}_{\mathrm{L166P}} \mathrm{Tg}$ mice & Hippocampus & 3 and 6 (mo) & $\uparrow$ RyR 2-3 protein & [111] \\
\hline
\end{tabular}

Abbreviations: $\left(^{*}\right)$ AD stage is defined following BRAAk's staging for human AD post-mortem brains, and is referred in weeks (W), months (mo) or years ( $\mathrm{Y}$ ) in $A D$ mice models, $\left(^{* *}\right)$ RyR expression (mRNA or protein level) is depicted as $\uparrow$ (increased), $\downarrow$ (reduced), or $\leftrightarrow$ (unchanged) as compared to respective controls, PS presenilin, $\mathrm{MCl}$ mild cognitive impairment, $K \mathrm{Kl}$ knock in, $\mathrm{Tg}$ transgenic, Wt wild type, CRDN8 Tg mice express human APP with a double mutation (APP $6670 \mathrm{~N} / \mathrm{M} 671 \mathrm{~L}+$ $\mathrm{APP}_{\mathrm{V} 717 \mathrm{~F}}$ ), PSCKO Tg mice are conditionally double knock out for PS1 and PS2, Tg2576 mice express the Swedish double mutation (APP695 $\left.670 \mathrm{~N} / \mathrm{M} 671 \mathrm{~L}\right), 3 \times \mathrm{xgAD}$ mice are generated from the PS1 $1_{\mathrm{M} 146 \mathrm{~V}} \mathrm{KI}$ mouse overexpressing $\mathrm{APP}_{\text {swe }}$ and $\mathrm{Tau}_{\mathrm{P} 130 \mathrm{~L}}$.

The molecular mechanisms that could underlie the regulation of RyR expression in $\mathrm{AD}$ are still unknown. ER stress is induced during $A D$, and has been indirectly implicated as a mediator of $A \beta$ neurotoxicity [113]. In this context, it was demonstrated that $A \beta$ triggered the activation of the ER stress response factor X-box binding protein 1 (XBP1), thereby yielding its transcriptionally spliced active form XBP1s. XBP1s showed neuroprotective activity towards $A \beta$ oligomers through a reduction of cytosolic $\mathrm{Ca}^{2+}$ and of the expression of RyR3 [114]. Human and murine RyR3 contains multiple XBP1s binding sites [114]. It is however still unclear whether the regulation of RyR3 by XBP1 is direct or indirect. Additional work is necessary to demonstrate these observations.

\section{The molecular link between Ryanodine Receptors and presenilins}

In many cases, the adverse effects of PS mutations on $\mathrm{Ca}^{2+}$ homeostasis were associated to RyR channels activity alteration. However, the molecular mechanism underlying this regulation is not fully understood. Nevertheless, RyRs were shown to co-localize with PSs at the ER membrane [96]. Co-immunoprecipitation experiments also unraveled a physical interaction between PS1-2 and RyR2 [95,96,115]. 
The laboratory of Peter Koulen further investigated the possible physical interaction of PS with RyR and studied in vitro the impact of such interaction on RyR channel activity. In two different studies, they demonstrated that PS1 and PS2 N-termini fragments strongly increased both mean currents and open probability of single brain RyR channels $[116,117]$. They proposed that PS1 NTF (1-82) and PS2 NTF (1-87) may interact with the cytoplasmic side of RyR and allosterically potentiates RyRs in a $\mathrm{Ca}^{2+}$-dependent manner [116,117]. Another group demonstrated the molecular interaction of the large hydrophylic C-terminal region of PS2 with sorcin, a modulator of RYR channel, in human derived neuronal cell line and in brain tissues. Their data also suggested that PS2/sorcin interaction is potentiated by $\mathrm{Ca}^{2+}[118]$. This observation was further confirmed in another cellular system where PS2, sorcin, and RyR2 were shown to physically interact (in a $\mathrm{Ca}^{2+}$ dependent manner) in both HEK-293 cells overexpressing these proteins and in mouse hearts [115].

All together this set of data demonstrates that PS may play an important role in RyR channel activity directly through the interaction of PS with RyR and indirectly through the interaction of PS with RyR modulators. However, the implication of such RyR channel function regulation by $\mathrm{PS}$ for $\mathrm{AD}$ remain to be elucidated (i.e. study of PS1-2 mutants physical interaction with RyR and the potential effect of such interactions on RyR channel activity).

\section{Post-translational Ryanodine Receptors modification in AD: just a hypothesis}

Enhanced RyR-mediated ER $\mathrm{Ca}^{2+}$ depletion may be linked to pathophysiological post-translational modifications in the macromolecular complex containing RyR1 or RyR2 resulting in "leaky channels" [45]. Interestingly, post-translational modifications of RyR2 were reported in cerebral ischemia [119] where endogenous RyRs undergo $\mathrm{S}$-nitrosylation and S-gluthathionylation processes that resulted in high activity channels and ultimately lead to cortical neuronal death [119]. Disrupting function of FKBP1b, a RYR2 stabilizer, was recently shown to alter $\mathrm{Ca}^{2+}$ homeostasis in hippocampal neurons and to trigger the aging phenotype of $\mathrm{Ca}^{2+}$ deregulation in young animals (i.e. enhanced ryanodine sensitive AHP "after hyperpolarization" signals, and increased CICR from RyR) [120]. Recently, Liu et al. described the contribution of "leaky" RyR2 to stress-related memory impairments [55]. Through a series of biochemical, neurophysiological, and behavioral assays, the study demonstrated that chronic stress can affect RyR2 function through PKA hyperphosphorylation, oxidation, and nitrosylation leading to the physical dissociation of FKBP12.6/1b (calstabin2) and RyR2, thereby inducing $\mathrm{Ca}^{2+}$ leak from RyRs and cognitive dysfunction [55].
Post-translational modifications of RyRs in AD have not been reported yet. However, AD brains manifest excessive generation of reactive nitrogen (RNS) and oxygen (ROS) species, contributing to neuronal cell injury and death via a series of redox reactions [121-123]. In addition, PKA activation was shown to be implicated in $\mathrm{AD}$ through the regulation of $\beta \mathrm{APP}$ processing [124-126], A $\beta$-mediated cell death in vitro and in vivo $[127,128]$, and oxidative stress. It is intriguing to note that RyR hyperphosphorylation is largely linked PKA activation [55,129]. Interestingly, a microarray analysis performed on CA1 hippocampal gray matter of Alzheimer and control subjects revealed the correlation of a down regulation of the expression of RyR stabilizers namely, FKBP1a with incipient AD, suggesting an additional mechanism involved in RyR dysfunction in AD [130]. All over, these observations must stimulate the initiation of dedicated studies investigating the influence of $\mathrm{RyR}$ destabilization in the onset and/or progression of AD.

\section{Ryanodine Receptors and $\beta$ APP processing}

It was reported that $\mathrm{Ca}^{2+}$ homeostasis may influence $\beta A P P$ pathophysiological processing. Thus, $A \beta$ production is enhanced by elevation of intracellular $\left[\mathrm{Ca}^{2+}\right]_{\mathrm{i}}[131,132]$ and RyR-mediated $\mathrm{Ca}^{2+}$ release [133], and is reduced in $\mathrm{IP}_{3} \mathrm{R}$-deficient lines [67]. Of particular interest, we showed that dantrolene-induced lowering of RyR-mediated $\mathrm{Ca}^{2+}$ release leads to the reduction of $\beta$ APP cleavage by $\beta$ - and $\gamma$-secretases and decreases both intracellular and extracellular $\mathrm{A} \beta$ load in wild type $\beta \mathrm{APP}$ - or $\beta_{\mathrm{APP}} \mathrm{swe}$ - overexpressing neuroblastoma cells as well as in primary cultured neurons derived from Tg2576 mice brain. We also demonstrated that this $A \beta$ reduction could be accounted for by decreased Thr-668-dependent $\beta$ APP phosphorylation and lowered $\beta$ - and $\gamma$-secretases activities [92]. Importantly, we and other laboratories showed that dantrolene diminishes $A \beta$ load, and reduces $A \beta$-related histological lesions in three different AD mice models (Tg2576, 3xTg$\mathrm{AD}$ and $\left.\mathrm{PS}_{\mathrm{M} 146 \mathrm{~V}} / \mathrm{APP}_{\text {swe }}\right)$, demonstrating that subchronic blockade of RyR activity may be beneficial in the context of $\mathrm{AD}[92,134,135]$. On the contrary, long-term feeding of dantrolene was shown to increase $A \beta$ load in $\mathrm{APP}_{\text {swe }} \mathrm{PS}_{\mathrm{L166 \textrm {P }}}$ transgenic mice [78].

Discrepancies in the above-described data may rely on the kinetics of AD-like set-up and progression as well as the duration of RyR blockade specifically linked to various models examined. These puzzling results may also point out a possible dual protective/compensatory versus pathogenic role of RyR at different stages of the development of AD.

The recent paper by Bezprozvanny's group sheds new lights on this complex dual role of RyR in the development of AD [111]. Authors used a genetic approach to modulate RyR expression along $\mathrm{AD}$ development in 
$\mathrm{APP}_{\text {swe }} \mathrm{PS}_{\mathrm{L} 166 \mathrm{P}}$ mice and generated APPPS1xRyR3-/mice as a study model. They demonstrate that the deletion of RyR3 in young APPPS1 mice elevates A $\beta$ accumulation, and increases hippocampal neuronal network excitability thus accelerating AD pathology. In contrast, the deletion of RyR3 in older APPPS1 mice reduces $A \beta$ plaques, and rescues the network excitability and the loss of mushroom spines [111].

All together, these studies suggest a complex dual role of RyR in AD pathology. RyR may function as a compensatory/protective actor at early disease stages, and acts as a pathogenic molecular determinant contributing to the setting of histopathological lesions and synaptic deficits observed at the late disease stages.

\section{Ryanodine Receptors and neurodegeneration}

RyR-mediated ER $\mathrm{Ca}^{2+}$ release leads unequivocally to large cytosolic $\mathrm{Ca}^{2+}$ signals. Thus, it could be postulated that enhanced RyR-mediated $\mathrm{Ca}^{2+}$ release may be indirectly implicated in neuronal death through cytosolic $\mathrm{Ca}^{2+}$ overload. Indeed, pharmacological targeting of RyR by its specific inhibitor, dantrolene suggested that this receptor could play a direct role in neurodegeneration. Popsecu et al. showed that dantrolene protected neurons against kainic acid-induced apoptosis in vitro and in vivo [136]. Neuroprotective effect of dantrolene was also reported in cerebral ischemia $[137,138]$, and in different neurodegenerative diseases such as Huntington's disease [139,140], and spinocerebellar ataxia of types 2 and 3 [141,142]. Dantrolene was shown to reduce the glutamate-induced increases in intracellular $\left[\mathrm{Ca}^{2+}\right]$, and protects against glutamate-induced neurotoxicity [143]. Complete block of glutamate toxicity by dantrolene was also observed in the absence of extracellular $\mathrm{Ca}^{2+}$, which indicates that $\mathrm{Ca}^{2+}$ release from intracellular stores is essential for the propagation of glutamate-induced neuronal damage [144].

Related to $\mathrm{AD}$, intracellular $\mathrm{Ca}^{2+}$ levels were increased in cells expressing the human $\mathrm{PS}_{\mathrm{L} 286 \mathrm{~V}}$ mutation. $\mathrm{A} \beta$ induced cell death in these cells and dantrolene protected the cells against these deleterious effects [145]. Imaizumi et al. showed that treatment of rat cortical neurons with $\mathrm{A} \beta$ increased the expression DP5, a neuronal apoptosisinducing gene [146]. Induction of DP5 gene expression was blocked by dantrolene suggesting that the induction of DP5 mRNA occurs downstream of the increase in cytosolic $\mathrm{Ca}^{2+}$ concentration caused by $\mathrm{A} \beta$. Moreover, DP5 specifically interacts with $\mathrm{Bcl}$-xl during neuronal apoptosis following exposure to $A \beta$, and its binding could impair the survival-promoting activities of Bcl-xl [146]. Accordingly, dantrolene treatment protected PC12 cells expressing $\mathrm{PS} 2_{\mathrm{N} 141 \mathrm{~L}}$ mutant from death induced by L-glutamate and $A \beta$ toxic peptides [96]. The direct implication of RyR in neuronal death was also proposed by Supnet et al. who showed that suppression of RyR3 expression in TgCRND8 neurons, increased neuronal death [91,147], thus supporting a protective role of RyR in the late stages of AD pathogenesis, at least in this mice model. According to this, other studies highlighted a potential protective role of RyR in AD models. Thus, long-term pharmacological blockade of RYR with dantrolene in $\mathrm{APP}_{\text {swe }} / \mathrm{PS}_{\mathrm{L} 166 \mathrm{P}}$ mice resulted in the loss of synaptic markers, and neuronal atrophy in hippocampal and cortical regions [78].

Based on these results, one could assume that alteration of RyR-mediated $\mathrm{Ca}^{2+}$ signals along AD pathogenesis progression may shift cell behavior from a protective/adaptive response to a pro-apoptotic phenotype.

Dantrolene-mediated neuroprotection may accur via the modulation of $\mathrm{Ca}^{2+}$-dependent proteases and kinases. Thus calpain, CaMKII, PKA, and MAPK that are all activated by cytosolic $\mathrm{Ca}^{2+}$ control the transcriptional activation of immediate early and memory genes [148,149]. It is noteworthy that the activated form of calpain2 is increased in neuritis and neurons at risk for developing neurofibrillary pathology and is extensively bound to neurofibrillary tangles in brain AD patients [150]. Interestingly, calpains inhibition was demonstrated to improve memory and synaptic transmission in AD models [149]. Calcineurin $\left(\mathrm{Ca}^{2+} /\right.$ calmodulin-dependent serine/threonine phosphatase) induces endocytosis of NMDA receptors, reduces synaptic currents and activates propoptotic molecules such as BAD [151]. Remarkably, Dinely et al. also reported that calcineurin is upregulated in the brain of Tg2576 mice model [152], and that the calcineurin inhibitor FK506 prevents the loss of mitochondrial potential induced by $\mathrm{A} \beta$ by preventing cytochrome $C$ release from mitochondria [153].

\section{Ryanodine Receptors-mediated synaptic dysfunction and learning and memory deficits in $A D$ Physiological role of RyR in synaptic function and memory formation and storage \\ Certain forms of $\mathrm{Ca}^{2+}$-dependent synaptic plasticity,} including long-term potentiation (LTP) and long-term depression (LTD), are thought to underlie the cellular/molecular mechanisms of learning and memory [154]. High concentration spikes of $\mathrm{Ca}^{2+}$ activate LTP. Information placed in this temporary memory is uploaded and consolidated in more permanent memory stores during certain phases of sleep. During another phase of sleep, smaller elevation in $\mathrm{Ca}^{2+}$ activates the LTD.

Pre-synaptically, CICR waves through the RyR trigger neurotransmitter release that is detected as a temporary depolarization of postsynaptic membrane potential (miniature postsynaptic potentials) [155]. CICR evoked by voltage-dependent $\mathrm{Ca}^{2+}$ entry can mobilize neurotransmitter vesicles from the reserve pool to the readily releasable pool and thus facilitate subsequent vesicle release [156]. This $\mathrm{Ca}^{2+}$-dependent release has implications for short-term forms of presynaptic plasticity known as paired 
pulse facilitation (PPF) [102,155]. Post-tetanic potentiation (PTP) (another form of presynaptic plasticity that occurs following a high frequency stimulus) is also thought to involve residual $\mathrm{Ca}^{2+}$ elevation that results from RyRmediated $\mathrm{Ca}^{2+}$ release $[155,157]$.

Post-synaptically, ER $\mathrm{Ca}^{2+}$ is involved in long- and short-term plasticity. Long-term changes in synaptic efficacy and plasticity depend on the combination of channels recruited in dendritic spines [158]. For example, NMDAR mediated- $\mathrm{Ca}^{2+}$ entry into spines and dendrites is essential but not sufficient for the induction of LTP $[156,159]$. ER $\mathrm{Ca}^{2+}$ stores can amplify the initial NMDAR-mediated signal and determine the polarity as well as input specificity to activate downstream cascades necessary to encode LTP or LTD [159]. As a matter of fact, blocking $\mathrm{IP}_{3} \mathrm{R}$ leads to a switch of LTD to LTP and elimination of heterosynaptic LTD, whereas blocking RyR eliminates both LTP and homosynaptic LTD occurring at synapses that are activated, normally at low frequencies [160-163]. Finally, type 3 RyR knockout mice were shown to harbor enhanced LTP and reduced LTD $[164,165]$.

$\mathrm{Ca}^{2+}$ partly regulates activity-dependent membrane excitability-sensitive $\mathrm{K}^{+}$channels, such as SK channel, which contribute to the medium after-hyperpolarization (known also as refractory period, where in neuron membrane potential falls below the resting membrane potential). This current underlies spike-frequency adaptation, a phenomenon wherein accumulating $\mathrm{Ca}^{2+}$ entering through spiking activity reaches sufficient levels to activate hyperpolarizing $\mathrm{K}^{+}$currents and transiently suppress membrane excitability. SK channels are largely activated by VGCC. However, $\mathrm{IP}_{3} \mathrm{R}$ - and RyR-mediated $\mathrm{Ca}^{2+}$ release were also shown to activate these channels and modify spiking patterns, thereby influencing local circuit activity [166].

\section{RyR-mediated synaptic dysfunction in AD}

Alteration of both RyR expression and function over time could have a significant effect on synaptic function that may contribute to cognitive decline. At the level of neuronal shape, augmented cytosolic $\mathrm{Ca}^{2+}$ leads to a loss of $\mathrm{Ca}^{2+}$ compartmentalization in dendritic spines and to a distortion of neurite morphologies mediated by activation of $\mathrm{Ca}^{2+}$-dependent phosphatase calcineurin [56]. Focusing on the role of RyR-mediated $\mathrm{Ca}^{2+}$ deregulation, Stutzmann's group provided a large amount of data supporting the major role of RyR expression and function deregulation in synaptic abnormalities in AD mice models $[72,100,135,165-168]$. They first revealed that $\mathrm{IP}_{3}$-evoked membrane hyperpolarization is driven by $\mathrm{Ca}^{2+}$ liberation through RyR and enhanced coupling efficiency between RyR and $\mathrm{Ca}^{2+}$-activated $\mathrm{K}^{+}$conductance [72,165]. Increased RyR-evoked $\mathrm{Ca}^{2+}$ release was shown to occur within synapse-dense regions of CA1 pyramidal neurons of young $3 \times \mathrm{Tg}-\mathrm{AD}$ mice and the double transgenic mice co-expressing mutated PS1 and $\beta \mathrm{APP}\left(\mathrm{PS}_{\mathrm{M} 146 \mathrm{~V}} / \mathrm{APP}_{\text {swe }}\right)$ and significantly increases the amplitude of spontaneous postsynaptic potentials and the frequency of events responses in 3xTg-AD as compared to non-transgenic neurons $[100,166]$. The obtained data also demonstrate that both presynaptic and postsynaptic RyR-sensitive $\mathrm{Ca}^{2+}$ stores contribute to synaptic transmission and plasticity in $3 x T g-A D$ but not in non-transgenic mice $[100,166]$. Interestingly, these signaling changes are present before $A \beta$ formation, tau deposits, or memory deficits thus revealing RyR function alteration may represent an early pathogenic process of AD $[100,166]$.

Recently, by using young 3xTg-AD mice, the same laboratory showed that under control conditions, basal synaptic transmission, PPF and LTP appear similar to the non-transgenic mice. However when RyRs are blocked and enhanced CICR effect was suppressed, the AD neurons demonstrated enhanced basal synaptic transmission and altered short and long term plasticity. This may suggest that RyR-mediated $\mathrm{Ca}^{2+}$ signals have a prominent inhibitory effect in basal synaptic transmission and presynaptic neurotransmitter release in the $\mathrm{AD}$ mice $[135,168]$. These data were further confirmed by showing that sub-chronic stabilization of ER $\mathrm{Ca}^{2+}$ signaling earlier in the disease process has beneficial effects on synaptic transmission and plasticity abnormalities in presymptomatic 3xTg-AD mice and adult $\mathrm{PS}_{\mathrm{M} 146 \mathrm{~V} /}$ $\mathrm{APP}_{\text {swe }}$ double transgenic mouse model, while having little effect in non-transgenic controls $[135,168]$.

\section{RyR-mediated learning and memory decline in $A D$}

Some evidences suggest that RyR expression levels may have a direct role in behavior and cognitive trait. It was shown that nicotine administration upregulates RyR2

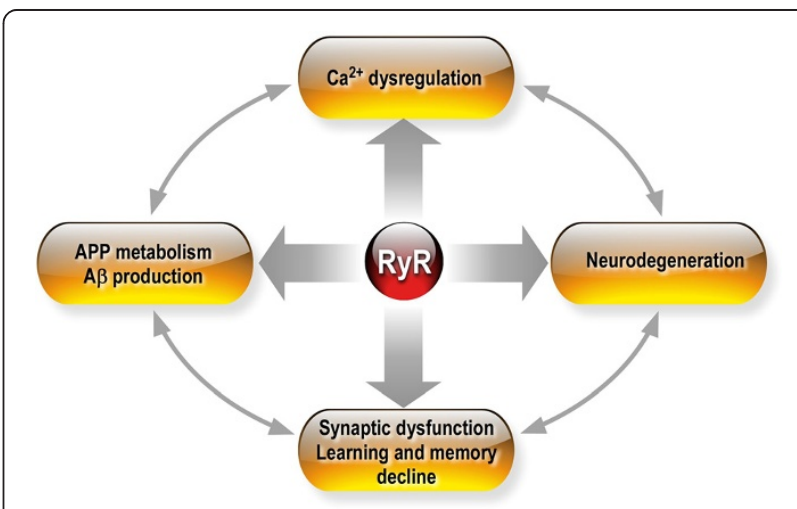

Figure 3 Scheme of the implication of RyR expression and function alterations in AD. RyR-mediated AD pathogenesis occurs through $\mathrm{Ca}^{2+}$ signaling dysregulation, the amplification of $\beta A P P$ metabolism and $A \beta$ peptide production, the control of neuronal death and degeneration, synaptic dysfunction, and learning and memory decline. The functional cross talk between these AD "pathological hallmarks" places RyR at the crossroads of AD pathogenesis. 
levels in brain areas that control cognitive and motivational systems (notably the cortex and ventral midbrain) [169]. Previous works have shown that RyR mRNA and protein levels in the hippocampus are upregulated in response to spatial learning tasks [170]. In agreement with the role of RyR in synaptic plasticity, it was reported that RyR may play a role in learning and memory. Thus, RyR3 knockout mice exhibit decreased social behavior [171], and memory retention is accompanied by increased expression of RyR2 mRNA in the hippocampus of water maze-trained rats as compared to swimming controls [172].

In the context of $\mathrm{AD}$, we demonstrated that dantrolene reduced $A \beta$ burden in Tg2576 mice in vivo. The influence of dantrolene on learning and memory decline was studied by means of two complementary tests: the Morris water maze (MWM), which examines spatial memory, and the novel object recognition (NOR) paradigm, which records recognition memory. Both tests revealed alterations of both learning and memory behavior in Tg2576 mice. Chronic treatment with dantrolene does not affect learning ability in wild type mice, but restores learning ability in Tg2576 mice (MWM test), and increased the object discrimination index when compared to vehicletreated Tg2576 mice (NOR test) [92]. According to these data, Peng et al. showed that chronic treatment with dantrolene reverses memory decline in the $3 x \mathrm{Tg}-\mathrm{AD}$ by using the MWM test [134].

We showed that Tg2576 mice harbor a reduced level of PSD-95 (a component of the post-synaptic density membrane associated guanylate kinase (PSD-MAGUK) scaffolding proteins) [92]. It is well established that PSDMAGUK indirectly regulates synaptic plasticity and memory through the control of the number and compartmentalization of both AMPA and NMDA glutamate receptors around the PSD (post-synaptic density) [173]. We hypothesized that excessive RyR-mediated $\mathrm{Ca}^{2+}$ release and subsequent increased $\mathrm{A} \beta$ load may have contributed to PSD-95 expression decline in Tg2576 mice which may have led directly or indirectly to learning and memory decline. The recently published paper by Liu et al. is in accordance with these findings since genetic depletion of RyR in old APPPS1 mice rescued neuronal network excitability [111].

\section{Conclusion}

Obviously, this review reveals RyR as a key molecular determinant in "AD $\mathrm{Ca}^{2+}$ hypothesis". It also highlights the molecular mechanisms that could influence RyRmediated $\mathrm{Ca}^{2+}$ release in $\mathrm{AD}$ where PS and $\mathrm{A} \beta$ emerge as detrminant regulators of RyR expression and function alteration.

Altered RyR levels have been described early in human $\mathrm{AD}$ cases, in mild cognitive impairment and in various
AD models [107,108]. Accordingly, deregulation of RyR function was reported in diverse in vitro and in vivo $\mathrm{AD}$ study models. Data interpretation concerning some controversial results about RyR deregulation in AD must take in consideration the divergence of study systems i.e.: i) simple versus double or triple transgenic mice models; ii) primary cultures neurons and acute hippocampal slices versus neuronal derived cell lines or fibroblasts; and most importantly iii) the time course of "AD pathogenesis" development in each study model. We have also to consider that $\mathrm{AD}$-associated neurodegeneration, synaptic dysfunction and cognitive decline are complex, inter-regulated and long processes where pathological and compensatory phenomenon may occur.

Actually, data converge to demonstrate a complex dual role of RyR in AD acting as a potential compensatory/protective paradigm, or as a pathological hallmark amplifying the setting of histopathological lesions and synaptic deficits that are associated with the late AD stages. We provide evidences that RyR interfere with different routes leading to $\mathrm{AD}$ pathogenesis development through the amplification of APP metabolism and A $\beta$ peptide production, the control of neuronal death, synaptic structure and plasticity dysfunctions and learning and memory decline (Figure 3).

About 30 millions individuals are estimated to be affected with AD worldwide and to date no effective treatment exists to arrest disease progression. Therapeutic approaches targeting $\mathrm{Ca}^{2+}$ influx have demonstrated efficacy in animal AD models but very few have been successful in clinical trials $[174,175]$. Targeting of ER $\mathrm{Ca}^{2+}$ homeostasis could be an additional therapeutic approach that merit testing. Data described above demonstrate that RyR could be envisaged as a potential new target. Therefore, we believe that it is of most interest to develop and test new RyR modulators with high specificity and affinity for RyR bioavailability as new therapeutic tools in AD.

\section{Abbreviations \\ Aß: Amyloid $\beta$ peptide; AD: Alzheimer Disease; AMPA: a-Amino-3-hydroxy-5- methyl-4-isoxazolepropionic acid; $\beta$ APP: $\beta$ Amyloid precursor protein; $\mathrm{Ca}^{2+}$ : Calcium; $\left[\mathrm{Ca}^{2+}\right]_{\text {cyt: }}$ Cytosolic calcium-concentration; $\left[\mathrm{Ca}^{2+}\right]$ ER: Endoplasmic reticulum calcium-concentration; CICR: $\mathrm{Ca}^{2+}$-induced $\mathrm{Ca}^{2+}$ release; ER: Endoplasmic reticulum; $\mathbb{I}_{3}$ : Inositol 1,4,5-triphosphate; $\mathrm{PP}_{3} \mathrm{R}$ : Inositol 1,4,5-triphosphate receptor; NMDA: N-methyl-D-aspartate; PS: Presenilin; RYR: Ryanodine receptor; SERCA: Sarco-Endoplasmic reticulum $\mathrm{Ca}^{2+}$-ATPase; VGCC: Voltage gated $\mathrm{Ca}^{2+}$ channel.}

\section{Competing interests}

The authors declare that they have no competing interests.

\section{Authors' contributions}

DDP drafted the first version of this review. MC and FC revised the manuscript for intellectual content. All authors read and approved the final manuscript.

\section{Acknowledgments}

This work was supported by INSERM, CNRS, «Fondation pour la Recherche Médicale» (DEQ20071210550) and LECMA (Ligue Européenne Contre la 
Maladie d'Alzheimer to MC). This work has been developed and supported through the LABEX (excellence laboratory, program investment for the future) DISTALZ (Development of Innovative Strategies for a Transdisciplinary approach to Alzheimer's disease). We acknowledge fellow support from BrightFocus foundation to D.D.P.

\section{Author details}

${ }^{1}$ Université de Nice Sophia Antipolis, IPMC, Sophia Antipolis, Nice, F-06560 Valbonne, France. ${ }^{2}$ CNRS, IPMC, Sophia Antipolis, Nice, F-06560 Valbonne, France. ${ }^{3}$ Present address: Albert Einstein College of Medicine, Bronx, New York 10461NY, USA.

Received: 14 January 2014 Accepted: 18 May 2014 Published: 5 June 2014

\section{References}

1. Lindeboom J, Weinstein $\mathrm{H}$ : Neuropsychology of cognitive ageing, minimal cognitive impairment, Alzheimer's disease, and vascular cognitive impairment. Eur J Pharmacol 2004, 490:83-86.

2. Checler F: Processing of the beta-amyloid precursor protein and its regulation in Alzheimer's disease. J Neurochem 1995, 65:1431-1444.

3. Wolfe MS: Processive proteolysis by gamma-secretase and the mechanism of Alzheimer's disease. Biol Chem 2012, 393:899-905.

4. Delacourte A, Buee L: Tau pathology: a marker of neurodegenerative disorders. Curr Opin Neurol 2000, 13:371-376.

5. St George-Hyslop PH, Tanzi RE, Haines JL, Polinsky RJ, Farrer L, Myers RH, Gusella JF: Molecular genetics of familial Alzheimer's disease. Eur Neurol 1989, 29(Suppl 3):25-27.

6. Tanzi RE, Bertram L: Twenty years of the Alzheimer's disease amyloid hypothesis: a genetic perspective. Cell 2005, 120:545-555.

7. Zhang YW, Thompson $\mathrm{R}$, Zhang H, Xu H: APP processing in Alzheimer's disease. Mol Brain 2011, 4:3

8. Golde TE, Cai XD, Shoji M, Younkin SG: Production of amyloid beta protein from normal amyloid beta-protein precursor (beta APP) and the mutated beta APPS linked to familial Alzheimer's disease. Ann N Y Acad Sci 1993, 695:103-108.

9. Wolfe MS: When loss is gain: reduced presenilin proteolytic function leads to increased Abeta42/Abeta40. talking point on the role of presenilin mutations in Alzheimer disease. EMBO Rep 2007, 8:136-140.

10. Berridge MJ, Bootman MD, Roderick HL: Calcium signalling: dynamics, homeostasis and remodelling. Nat Rev Mol Cell Biol 2003, 4:517-529.

11. Berridge MJ, Bootman MD, Lipp P: Calcium-a life and death signal. Nature 1998, 395:645-648.

12. Meldolesi J, Pozzan T: The endoplasmic reticulum Ca2+ store: a view from the lumen. Trends Biochem Sci 1998, 23:10-14

13. Dailey ME, Bridgman PC: Dynamics of the endoplasmic reticulum and other membranous organelles in growth cones of cultured neurons. J Neurosci 1989, 9:1897-1909.

14. Berridge MJ: The endoplasmic reticulum: a multifunctional signaling organelle. Cell Calcium 2002, 32:235-249.

15. Holbro N, Grunditz A, Oertner TG: Differential distribution of endoplasmic reticulum controls metabotropic signaling and plasticity at hippocampal synapses. Proc Natl Acad Sci U S A 2009, 106:15055-15060.

16. Emptage NJ, Reid CA, Fine A: Calcium stores in hippocampal synaptic boutons mediate short-term plasticity, store-operated Ca2+ entry, and spontaneous transmitter release. Neuron 2001, 29:197-208.

17. Li W, Llopis J, Whitney M, Zlokarnik G, Tsien RY: Cell-permeant caged InsP3 ester shows that Ca2+ spike frequency can optimize gene expression. Nature 1998, 392:936-941.

18. Bandtlow CE, Schmidt MF, Hassinger TD, Schwab ME, Kater SB: Role of intracellular calcium in NI-35-evoked collapse of neuronal growth cones. Science 1993, 259:80-83.

19. Khachaturian ZS: Calcium, membranes, aging, and Alzheimer's disease. introduction and overview. Ann N Y Acad Sci 1989, 568:1-4.

20. Bezprozvanny I, Mattson MP: Neuronal calcium mishandling and the pathogenesis of Alzheimer's disease. Trends Neurosci 2008, 31:454-463.

21. Supnet C, Bezprozvanny l: The dysregulation of intracellular calcium in Alzheimer disease. Cell Calcium 2010, 47:183-189.

22. Chakroborty S, Stutzmann GE: Calcium channelopathies and Alzheimer's disease: insight into therapeutic success and failures. Eur J Pharmacol
2013, pii: S0014-2999(13):00883-2. doi:10.1016/j.ejphar.2013.11.012. [Epub ahead of print]. PMID: 24316360.

23. Popugaeva E, Bezprozvanny I: Can the calcium hypothesis explain synaptic loss in Alzheimer's disease? Neurodegener Dis 2014, 13:139-141.

24. Mattson MP: ER calcium and Alzheimer's disease: in a state of flux. SCi Signal 2010, 3:pe10.

25. Stutzmann GE, Mattson MP: Endoplasmic reticulum $\mathrm{Ca}(2+)$ handling in excitable cells in health and disease. Pharmacol Rev 2011, 63:700-727.

26. Giannini G, Conti A, Mammarella S, Scrobogna M, Sorrentino V: The ryanodine receptor/calcium channel genes are widely and differentially expressed in murine brain and peripheral tissues. J Cell Biol 1995, 128:893-904.

27. Zalk R, Lehnart SE, Marks AR: Modulation of the ryanodine receptor and intracellular calcium. Annu Rev Biochem 2007, 76:367-385.

28. Murayama T, Ogawa Y: Characterization of type 3 ryanodine receptor (RyR3) of sarcoplasmic reticulum from rabbit skeletal muscles. J Biol Chem 1997, 272:24030-24037.

29. Chen SR, Leong P, Imredy JP, Bartlett C, Zhang L, MacLennan DH: Singlechannel properties of the recombinant skeletal muscle Ca2+ release channel (ryanodine receptor). Biophys J 1997, 73:1904-1912.

30. Usachev Y, Shmigol A, Pronchuk N, Kostyuk P, Verkhratsky A: Caffeineinduced calcium release from internal stores in cultured rat sensory neurons. Neuroscience 1993, 57:845-859.

31. Korkotian E, Segal M: Fast confocal imaging of calcium released from stores in dendritic spines. Eur J Neurosci 1998, 10:2076-2084.

32. Meissner G: Ryanodine activation and inhibition of the Ca2+ release channel of sarcoplasmic reticulum. J Biol Chem 1986, 261:6300-6306.

33. Laver DR, Baynes TM, Dulhunty AF: Magnesium inhibition of ryanodinereceptor calcium channels: evidence for two independent mechanisms. J Membr Biol 1997, 156:213-229.

34. Laver DR, Owen VJ, Junankar PR, Taske NL, Dulhunty AF, Lamb GD: Reduced inhibitory effect of $\mathrm{Mg} 2+$ on ryanodine receptor-Ca2+ release channels in malignant hyperthermia. Biophys J 1997, 73:1913-1924.

35. Snyder HR Jr, Davis CS, Bickerton RK, Halliday RP: 1-[(5-arylfurfurylidene)amino] hydantoins. a new class of muscle relaxants. J Med Chem 1967, 10:807-810.

36. Kolb ME, Horne ML, Martz R: Dantrolene in human malignant hyperthermia. Anesthesiology 1982, 56:254-262.

37. Fruen BR, Mickelson JR, Louis CF: Dantrolene inhibition of sarcoplasmic reticulum $\mathrm{Ca} 2+$ release by direct and specific action at skeletal muscle ryanodine receptors. J Biol Chem 1997, 272:26965-26971.

38. Zhao F, Li P, Chen SR, Louis CF, Fruen BR: Dantrolene inhibition of ryanodine receptor $\mathrm{Ca} 2+$ release channels. molecular mechanism and isoform selectivity. J Biol Chem 2001, 276:13810-13816.

39. Paul-Pletzer K, Yamamoto $T$, Ikemoto $N$, Jimenez LS, Morimoto $H$, Williams PG, Ma J, Parness J: Probing a putative dantrolene-binding site on the cardiac ryanodine receptor. Biochem J 2005, 387:905-909.

40. Wang R, Zhong X, Meng X, Koop A, Tian X, Jones PP, Fruen BR, Wagenknecht T, Liu Z, Chen SR: Localization of the dantrolene-binding sequence near the FK506-binding protein-binding site in the threedimensional structure of the ryanodine receptor. J Biol Chem 2011, 286:12202-12212.

41. Kobayashi S, Yano M, Suetomi T, Ono M, Tateishi H, Mochizuki M, Xu X, Uchinoumi H, Okuda S, Yamamoto T, Koseki N, Kyushiki H, Ikemoto N, Matsuzaki M: Dantrolene, a therapeutic agent for malignant hyperthermia, markedly improves the function of failing cardiomyocytes by stabilizing interdomain interactions within the ryanodine receptor. J Am Coll Cardiol 2009, 53:1993-2005.

42. Maxwell JT, Domeier TL, Blatter LA: Dantrolene prevents arrhythmogenic Ca2+ release in heart failure. Am J Physiol Heart Circ Physiol 2012, 302:H953-H963

43. Jung $C B$, Moretti $A$, Mederos y Schnitzler M, lop L, Storch U, Bellin M, Dorn T, Ruppenthal S, Pfeiffer S, Goedel A, Dirschinger RJ, Seyfarth M, Lam JT, Sinnecker D, Gudermann T, Lipp P, Laugwitz KL: Dantrolene rescues arrhythmogenic RYR2 defect in a patient-specific stem cell model of catecholaminergic polymorphic ventricular tachycardia. EMBO Mol Med 2012, 4:180-191

44. Zhao X, Weisleder N, Han X, Pan Z, Parness J, Brotto M, Ma J. Azumolene inhibits a component of store-operated calcium entry coupled to the skeletal muscle ryanodine receptor. J Biol Chem 2006, 281:33477-33486.

45. Lanner JT, Georgiou DK, Joshi AD, Hamilton SL: Ryanodine receptors: structure, expression, molecular details, and function in calcium release. Cold Spring Harb Perspect Biol 2010, 2:a003996. 
46. Balshaw DM, Yamaguchi N, Meissner G: Modulation of intracellular calcium-release channels by calmodulin. J Membr Biol 2002, 185:1-8.

47. MacMillan D: FK506 binding proteins: cellular regulators of intracellular Ca2+ signalling. Eur J Pharmacol 2013, 700:181-193.

48. Currie S: Cardiac ryanodine receptor phosphorylation by CaM Kinase II: keeping the balance right. Front Biosci (Landmark Ed) 2009, 14:5134-5156.

49. Valdivia $\mathrm{HH}$ : Modulation of intracellular $\mathrm{Ca} 2+$ levels in the heart by sorcin and FKBP12, two accessory proteins of ryanodine receptors. Trends Pharmacol Sci 1998, 19:479-482.

50. Zhang L, Kelley J, Schmeisser G, Kobayashi YM, Jones LR: Complex formation between junctin, triadin, calsequestrin, and the ryanodine receptor. Proteins of the cardiac junctional sarcoplasmic reticulum membrane. J Biol Chem 1997, 272:23389-23397.

51. Andersson DC, Betzenhauser MJ, Reiken S, Meli AC, Umanskaya A, Xie W, Shiomi T, Zalk R, Lacampagne A, Marks AR: Ryanodine receptor oxidation causes intracellular calcium leak and muscle weakness in aging. Cell Metab 2011, 14:196-207.

52. Bellinger AM, Reiken S, Carlson C, Mongillo M, Liu X, Rothman L, Matecki S, Lacampagne A, Marks AR: Hypernitrosylated ryanodine receptor calcium release channels are leaky in dystrophic muscle. Nat Med 2009, 15:325-330.

53. Bellinger AM, Reiken S, Dura M, Murphy PW, Deng SX, Landry DW, Nieman D, Lehnart SE, Samaru M, LaCampagne A, Marks AR: Remodeling of ryanodine receptor complex causes "leaky" channels: a molecular mechanism for decreased exercise capacity. Proc Natl Acad Sci U S A 2008, 105:2198-2202.

54. Fauconnier J, Meli AC, Thireau J, Roberge S, Shan J, Sassi Y, Reiken SR, Rauzier JM, Marchand A, Chauvier D, Cassan C, Crozier C, Bideaux P, Lompré AM, Jacotot E, Marks AR, Lacampagne A: Ryanodine receptor leak mediated by caspase- 8 activation leads to left ventricular injury after myocardial ischemia-reperfusion. Proc Natl Acad Sci U S A 2011, 108:13258-13263.

55. Liu X, Betzenhauser MJ, Reiken S, Meli AC, Xie W, Chen BX, Arancio O, Marks AR: Role of leaky neuronal ryanodine receptors in stress-induced cognitive dysfunction. Cell 2012, 150:1055-1067.

56. Kuchibhotla KV, Goldman ST, Lattarulo CR, Wu HY, Hyman BT, Bacskai BJ: Abeta plaques lead to aberrant regulation of calcium homeostasis in vivo resulting in structural and functional disruption of neuronal networks. Neuron 2008, 59:214-225.

57. Busche MA, Eichhoff $G$, Adelsberger $H$, Abramowski D, Wiederhold KH, Haass C, Staufenbiel M, Konnerth A, Garaschuk O: Clusters of hyperactive neurons near amyloid plaques in a mouse model of Alzheimer's disease. Science 2008, 321:1686-1689.

58. Demuro A, Mina E, Kayed R, Milton SC, Parker I, Glabe CG: Calcium dysregulation and membrane disruption as a ubiquitous neurotoxic mechanism of soluble amyloid oligomers. J Bio/ Chem 2005, 280:17294-17300.

59. Mattson MP, Cheng B, Davis D, Bryant K, Lieberburg I, Rydel RE: betaAmyloid peptides destabilize calcium homeostasis and render human cortical neurons vulnerable to excitotoxicity. J Neurosci 1992, 12:376-389.

60. Simakova O, Arispe NJ: Early and late cytotoxic effects of external application of the Alzheimer's Abeta result from the initial formation and function of Abeta ion channels. Biochemistry 2006, 45:5907-5915.

61. Simakova O, Arispe NJ: The cell-selective neurotoxicity of the Alzheimer's Abeta peptide is determined by surface phosphatidylserine and cytosolic ATP levels. membrane binding is required for Abeta toxicity. J Neurosci 2007, 27:13719-13729.

62. Arispe N, Rojas E, Pollard HB: Alzheimer disease amyloid beta protein forms calcium channels in bilayer membranes: blockade by tromethamine and aluminum. Proc Natl Acad Sci U S A 1993, 90:567-571.

63. Ferreiro $E$, Oliveira $C R$, Pereira $C$ : Involvement of endoplasmic reticulum $\mathrm{Ca} 2+$ release through ryanodine and inositol 1,4,5-triphosphate receptors in the neurotoxic effects induced by the amyloid-beta peptide. J Neurosci Res 2004, 76:872-880.

64. Niu Y, Su Z, Zhao C, Song B, Zhang X, Zhao N, Shen X, Gong Y: Effect of amyloid beta on capacitive calcium entry in neural 2a cells. Brain Res Bull 2009, 78:152-157.

65. Demuro A, Parker I: Cytotoxicity of intracellular abeta42 amyloid oligomers involves $\mathrm{Ca} 2+$ release from the endoplasmic reticulum by stimulated production of inositol trisphosphate. J Neurosci 2013, 33:3824-3833.

66. Renner M, Lacor PN, Velasco PT, Xu J, Contractor A, Klein WL, Triller A: Deleterious effects of amyloid beta oligomers acting as an extracellular scaffold for mGluR5. Neuron 2010, 66:739-754.
67. Cheung KH, Shineman D, Muller M, Cardenas C, Mei L, Yang J, Tomita T, Iwatsubo T, Lee VM, Foskett JK: Mechanism of Ca2+ disruption in Alzheimer's disease by presenilin regulation of InsP(3) receptor channel gating. Neuron 2008, 58:871-883.

68. Ito E, Oka K, Etcheberrigaray R, Nelson TJ, McPhie DL, Tofel-Grehl B, Gibson $\mathrm{GE}$, Alkon DL: Internal Ca2+ mobilization is altered in fibroblasts from patients with Alzheimer disease. Proc Natl Acad Sci U S A 1994, 91:534-538

69. Etcheberrigaray R, Hirashima N, Nee L, Prince J, Govoni S, Racchi M, Tanzi $\mathrm{RE}$, Alkon DL: Calcium responses in fibroblasts from asymptomatic members of Alzheimer's disease families. Neurobiol Dis 1998, 5:37-45.

70. Leissring MA, Parker I, LaFerla FM: Presenilin-2 mutations modulate amplitude and kinetics of inositol 1, 4,5-trisphosphate-mediated calcium signals. J Biol Chem 1999, 274:32535-32538.

71. Stutzmann GE, Caccamo A, LaFerla FM, Parker I: Dysregulated IP3 signaling in cortical neurons of knock-in mice expressing an Alzheimer's-linked mutation in presenilin 1 results in exaggerated $\mathrm{Ca} 2+$ signals and altered membrane excitability. J Neurosci 2004, 24:508-513.

72. Stutzmann GE, Smith I, Caccamo A, Oddo S, Laferla FM, Parker I: Enhanced ryanodine receptor recruitment contributes to $\mathrm{Ca} 2+$ disruptions in young, adult, and aged Alzheimer's disease mice. J Neurosci 2006, 26:5180-5189.

73. Green KN, Demuro A, Akbari Y, Hitt BD, Smith IF, Parker I, LaFerla FM: SERCA pump activity is physiologically regulated by presenilin and regulates amyloid beta production. J Cell Biol 2008, 181:1107-1116.

74. Tu H, Nelson O, Bezprozvanny A, Wang Z, Lee SF, Hao YH, Serneels L, De Strooper B, Yu G, Bezprozvanny I: Presenilins form ER Ca2+ leak channels, a function disrupted by familial Alzheimer's disease-linked mutations. Cell 2006, 126:981-993.

75. Brunello L, Zampese E, Florean C, Pozzan T, Pizzo P, Fasolato C: Presenilin-2 dampens intracellular Ca2+ stores by increasing Ca2+ leakage and reducing Ca2+ uptake. J Cell Mol Med 2009, 13:3358-3369.

76. Nelson O, Supnet C, Liu H, Bezprozvanny I: Familial Alzheimer's disease mutations in presenilins: effects on endoplasmic reticulum calcium homeostasis and correlation with clinical phenotypes. J Alzheimers Dis 2010, 21:781-793.

77. Nelson O, Tu H, Lei T, Bentahir M, de Strooper B, Bezprozvanny I: Familial Alzheimer disease-linked mutations specifically disrupt Ca2+ leak function of presenilin 1. J Clin Invest 2007, 117:1230-1239.

78. Zhang H, Sun S, Herreman A, De Strooper B, Bezprozvanny I: Role of presenilins in neuronal calcium homeostasis. J Neurosci 2010, 30:8566-8580.

79. Nelson O, Supnet C, Tolia A, Horre K, De Strooper B, Bezprozvanny I: Mutagenesis mapping of the presenilin 1 calcium leak conductance pore. J Biol Chem 2011, 286:22339-22347.

80. Shilling D, Mak DO, Kang DE, Foskett JK: Lack of evidence for presenilins as endoplasmic reticulum Ca2+ leak channels. J Biol Chem 2012, 287 (14):10933-10944.

81. Bezprozvanny I, Supnet C, Sun S, Zhang H, De Strooper B: Response to Shilling et al. J Bio/ Chem 2012, 287:20469. 10.1074/jbc.M111.300491. author reply 20470.

82. Das HK, Tchedre K, Mueller B: Repression of transcription of presenilin-1 inhibits gamma-secretase independent $\mathrm{ER} \mathrm{Ca}(2)(+)$ leak that is impaired by FAD mutations. J Neurochem 2012, 122:487-500.

83. Bandara S, Malmersjo S, Meyer T: Regulators of calcium homeostasis identified by inference of kinetic model parameters from live single cells perturbed by siRNA. Sci Signal 2013, 6:ra56.

84. Furukawa K, Barger SW, Blalock EM, Mattson MP: Activation of K+ channels and suppression of neuronal activity by secreted beta-amyloid-precursor protein. Nature 1996, 379:74-78.

85. Cao X, Sudhof TC: A transcriptionally [correction of transcriptively] active complex of APP with Fe65 and histone acetyltransferase Tip60. Science 2001, 293:115-120.

86. Leissring MA, Murphy MP, Mead TR, Akbari Y, Sugarman MC, Jannatipour M, Anliker B, Müller U, Saftig P, De Strooper B, Wolfe MS, Golde TE, LaFerla FM: A physiologic signaling role for the gamma -secretase-derived intracellular fragment of APP. Proc Natl Acad Sci U S A 2002, 99:4697-4702.

87. Pardossi-Piquard R, Checler F: The physiology of the beta-amyloid precursor protein intracellular domain AICD. J Neurochem 2012, 120(Suppl 1):109-124.

88. Raychaudhuri M, Mukhopadhyay D: AICD Overexpression in neuro 2A cells regulates expression of PTCH1 and TRPC5. Int J Alzheimers Dis 2011, pii: 239453. doi:10.4061/2011/239453.

89. Chatzistavraki M, Kyratzi E, Fotinopoulou A, Papazafiri P, Efthimiopoulos S: Downregulation of AbetaPP enhances both calcium content of 
endoplasmic reticulum and acidic stores and the dynamics of store operated calcium channel activity. J Alzheimers Dis 2013, 34:407-415.

90. Gibson GE, Vestling M, Zhang H, Szolosi S, Alkon D, Lannfelt L, Gandy S, Cowburn RF: Abnormalities in Alzheimer's disease fibroblasts bearing the APP670/671 mutation. Neurobiol Aging 1997, 18:573-580.

91. Supnet C, Grant J, Kong H, Westaway D, Mayne M: Amyloid-beta-(1-42) increases ryanodine receptor-3 expression and function in neurons of TgCRND8 mice. J Biol Chem 2006, 281:38440-38447.

92. Oulès B, Del Prete D, Greco B, Zhang X, Lauritzen I, Sevalle J, Moreno S, PaterliniBréchot $P$, Trebak M, Checler F, Benfenati F, Chami M: Ryanodine receptor blockade reduces amyloid-beta load and memory impairments in Tg2576 mouse model of Alzheimer disease. J Neurosci 2012, 32:11820-11834.

93. Popescu BO, Cedazo-Minguez A, Benedikz E, Nishimura T, Winblad B, Ankarcrona M, Cowburn RF: Gamma-secretase activity of presenilin 1 regulates acetylcholine muscarinic receptor-mediated signal transduction. J Biol Chem 2004, 279:6455-6464.

94. Smith IF, Hitt B, Green KN, Oddo S, LaFerla FM: Enhanced caffeine-induced $\mathrm{Ca} 2+$ release in the $3 \times \mathrm{Tg}-\mathrm{AD}$ mouse model of Alzheimer's disease. J Neurochem 2005, 94:1711-1718.

95. Chan SL, Mayne M, Holden CP, Geiger JD, Mattson MP: Presenilin-1 mutations increase levels of ryanodine receptors and calcium release in PC12 cells and cortical neurons. J Biol Chem 2000, 275:18195-18200.

96. Lee SY, Hwang DY, Kim YK, Lee JW, Shin IC, Oh KW, Lee MK, Lim JS, Yoon DY, Hwang SJ, Hong JT: PS2 mutation increases neuronal cell vulnerability to neurotoxicants through activation of caspase-3 by enhancing of ryanodine receptor-mediated calcium release. FASEB 2006, 20:151-153.

97. Wu B, Yamaguchi H, Lai FA, Shen J: Presenilins regulate calcium homeostasis and presynaptic function via ryanodine receptors in hippocampal neurons. Proc Natl Acad Sci U S A 2013, 110:15091-15096.

98. Saura CA, Choi SY, Beglopoulos V, Malkani S, Zhang D, Shankaranarayana Rao BS, Chattarji S, Kelleher RJ III, Kandel ER, Duff K, Kirkwood A, Shen J: Loss of presenilin function causes impairments of memory and synaptic plasticity followed by age-dependent neurodegeneration. Neuron 2004, 42:23-36.

99. Zhang C, Wu B, Beglopoulos V, Wines-Samuelson M, Zhang D, Dragatsis Sudhof TC, Shen J: Presenilins are essential for regulating neurotransmitter release. Nature 2009, 460:632-636.

100. Chakroborty S, Goussakov I, Miller MB, Stutzmann GE: Deviant ryanodine receptor-mediated calcium release resets synaptic homeostasis in presymptomatic 3xTg-AD mice. J Neurosci 2009, 29:9458-9470.

101. Kipanyula MJ, Contreras L, Zampese E, Lazzari C, Wong AK, Pizzo P, Fasolato C, Pozzan T: Ca2+ dysregulation in neurons from transgenic mice expressing mutant presenilin 2. Aging Cell 2012, 11:885-893.

102. Goussakov I, Miller MB, Stutzmann GE: NMDA-mediated Ca(2+) influx drives aberrant ryanodine receptor activation in dendrites of young Alzheimer's disease mice. J Neurosci 2010, 30:12128-12137.

103. Lopez JR, Lyckman A, Oddo S, Laferla FM, Querfurth HW, Shtifman A: Increased intraneuronal resting $[\mathrm{Ca}(2+)]$ in adult Alzheimer's disease mice. J Neurochem 2008, 105(1):262-271.

104. Rojas G, Cardenas AM, Fernandez-Olivares P, Shimahara T, Segura-Aguilar J, Caviedes R, Caviedes P: Effect of the knockdown of amyloid precursor protein on intracellular calcium increases in a neuronal cell line derived from the cerebral cortex of a trisomy 16 mouse. Exp Neurol 2008, 209:234-242.

105. Paula-Lima AC, Hidalgo C: Amyloid beta-peptide oligomers, ryanodine receptor-mediated $\mathrm{Ca}(2+)$ release, and $\mathrm{Wnt}-5 \mathrm{a} / \mathrm{Ca}(2+)$ signaling: opposing roles in neuronal mitochondrial dynamics? Front Cell Neurosci 2013, 7:120.

106. Shtifman A, Ward CW, Laver DR, Bannister ML, Lopez JR, Kitazawa M, LaFerla FM, Ikemoto N, Querfurth HW: Amyloid-beta protein impairs Ca2+ release and contractility in skeletal muscle. Neurobiol Aging 2010, 31:2080-2090.

107. Kelliher M, Fastbom J, Cowburn RF, Bonkale W, Ohm TG, Ravid R, Sorrentino $\mathrm{V}, \mathrm{O}^{\prime} \mathrm{Neill} \mathrm{C}$ : Alterations in the ryanodine receptor calcium release channel correlate with Alzheimer's disease neurofibrillary and betaamyloid pathologies. Neuroscience 1999, 92:499-513.

108. Bruno AM, Huang JY, Bennett DA, Marr RA, Hastings ML, Stutzmann GE: Altered ryanodine receptor expression in mild cognitive impairment and Alzheimer's disease. Neurobiol Aging 2012, 33:1001-1006.

109. Antonell A, Lladó A, Altirriba J, Botta-Orfila T, Balasa M, Fernández M, Ferrer I, Sánchez-Valle R, Molinuevo JL: A preliminary study of the whole- genome expression profile of sporadic and monogenic early-onset Alzheimer's disease. Neurobiol Aging 2013, 34:1772-1778.

110. Stutzmann GE, Smith I, Caccamo A, Oddo S, Parker I, Laferla F: Enhanced ryanodine-mediated calcium release in mutant PS1-expressing Alzheimer's mouse models. Ann N Y Acad Sci 2007, 1097:265-277.

111. Liu J, Supnet C, Sun S, Zhang H, Good L, Popugaeva E, Bezprozvanny I: The role of ryanodine receptor type 3 in a mouse model of Alzheimer disease. Channels (Austin) 2014, 8(3): $\boldsymbol{\otimes}$ [Epub ahead of print].

112. Paula-Lima AC, Adasme T, SanMartin C, Sebollela A, Hetz C, Carrasco MA Ferreira ST, Hidalgo C: Amyloid beta-peptide oligomers stimulate RyRmediated $\mathrm{Ca} 2+$ release inducing mitochondrial fragmentation in hippocampal neurons and prevent RyR-mediated dendritic spine remodeling produced by BDNF. Antioxid Redox Signal 2011, 14:1209-1223.

113. Chami $L$, Checler F: BACE1 is at the crossroad of a toxic vicious cycle involving cellular stress and beta-amyloid production in Alzheimer's disease. Mol Neurodegener 2012, 7:52

114. Casas-Tinto S, Zhang Y, Sanchez-Garcia J, Gomez-Velazquez M, Rincon-Limas DE, Fernandez-Funez P: The ER stress factor XBP1s prevents amyloid-beta neurotoxicity. Hum Mol Genet 2011, 20:2144-2160.

115. Takeda T, Asahi M, Yamaguchi O, Hikoso S, Nakayama H, Kusakari Y, Kawai M, Hongo K, Higuchi Y, Kashiwase K, Watanabe T, Taniike M, Nakai A Nishida K, Kurihara S, Donoviel DB, Bernstein A, Tomita T, Iwatsubo T, Hori $\mathrm{M}$, Otsu K: Presenilin 2 regulates the systolic function of heart by modulating Ca2+ signaling. FASEB J 2005, 19:2069-2071.

116. Hayrapetyan V, Rybalchenko V, Rybalchenko N, Koulen P: The N-terminus of presenilin- 2 increases single channel activity of brain ryanodine receptors through direct protein-protein interaction. Cell Calcium 2008, 44:507-518.

117. Rybalchenko V, Hwang SY, Rybalchenko N, Koulen P: The cytosolic Nterminus of presenilin-1 potentiates mouse ryanodine receptor single channel activity. Int J Biochem Cell Biol 2008, 40:84-97.

118. Pack-Chung E, Meyers MB, Pettingell WP, Moir RD, Brownawell AM, Cheng I, Tanzi RE, Kim TW: Presenilin 2 interacts with sorcin, a modulator of the ryanodine receptor. J Biol Chem 2000, 275:14440-14445.

119. Bull R, Finkelstein JP, Galvez J, Sanchez G, Donoso P, Behrens Ml, Hidalgo C: Ischemia enhances activation by $\mathrm{Ca} 2+$ and redox modification of ryanodine receptor channels from rat brain cortex. J Neurosci 2008, 28:9463-9472.

120. Gant JC, Chen KC, Norris CM, Kadish I, Thibault O, Blalock EM, Porter NM, Landfield PW: Disrupting function of FK506-binding protein 1b/12.6 induces the $\mathrm{Ca}(2)+-$ dysregulation aging phenotype in hippocampal neurons. J Neurosci 2011, 31:1693-1703.

121. Barnham KJ, Haeffner F, Ciccotosto GD, Curtain CC, Tew D, Mavros C, Beyreuther K, Carrington D, Masters CL, Cherny RA, Cappai R, Bush Al: Tyrosine gated electron transfer is key to the toxic mechanism of Alzheimer's disease beta-amyloid. FASEB J 2004, 18:1427-1429.

122. Emerit J, Edeas M, Bricaire F: Neurodegenerative diseases and oxidative stress. Biomed Pharmacother 2004, 58:39-46.

123. Lin MT, Beal MF: Mitochondrial dysfunction and oxidative stress in neurodegenerative diseases. Nature 2006, 443:787-795.

124. Su Y, Ryder J, Ni B: Inhibition of Abeta production and APP maturation by a specific PKA inhibitor. FEBS Lett 2003, 546:407-410.

125. Marambaud P, Chevallier N, Ancolio K, Checler F: Post-transcriptional contribution of a CAMP-dependent pathway to the formation of alphaand beta/gamma-secretases-derived products of beta APP maturation in human cells expressing wild-type and Swedish mutated beta APP. Mol Med 1998, 4:715-723.

126. Marambaud P, Ancolio K, Alves da Costa C, Checler F: Effect of protein kinase $A$ inhibitors on the production of Abeta40 and Abeta42 by human cells expressing normal and Alzheimer's disease-linked mutated betaAPP and presenilin 1. Br J Pharmacol 1999, 126:1186-1190.

127. Ueda K, Yagami T, Kageyama H, Kawasaki K: Protein kinase inhibitor attenuates apoptotic cell death induced by amyloid beta protein in culture of the rat cerebral cortex. Neurosci Lett 1996, 203:175-178.

128. Eftekharzadeh B, Ramin M, Khodagholi F, Moradi S, Tabrizian K, Sharif R, Azami K, Beyer C, Sharifzadeh M: Inhibition of PKA attenuates memory deficits induced by beta-amyloid (1-42), and decreases oxidative stress and NF-kappaB transcription factors. Behav Brain Res 2012, 226:301-308.

129. Hui L, Hong Y, Jingjing Z, Yuan H, Qi C, Nong Z: HGF suppresses high glucose-mediated oxidative stress in mesangial cells by activation of PKG and inhibition of PKA. Free Radic Biol Med 2010, 49:467-473.

130. Blalock EM, Chen KC, Sharrow K, Herman JP, Porter NM, Foster TC, Landfield PW: Gene microarrays in hippocampal aging: statistical profiling 
identifies novel processes correlated with cognitive impairment. J Neurosci 2003, 23:3807-3819.

131. Buxbaum JD, Ruefli AA, Parker CA, Cypess AM, Greengard P: Calcium regulates processing of the Alzheimer amyloid protein precursor in a protein kinase C-independent manner. Proc Natl Acad Sci U S A 1994, 91:4489-4493.

132. Querfurth HW, Selkoe DJ: Calcium ionophore increases amyloid beta peptide production by cultured cells. Biochemistry 1994, 33:4550-4561.

133. Querfurth HW, Jiang J, Geiger JD, Selkoe DJ: Caffeine stimulates amyloid beta-peptide release from beta-amyloid precursor protein-transfected HEK293 cells. J Neurochem 1997, 69:1580-1591.

134. Peng J, Liang G, Inan S, Wu Z, Joseph DJ, Meng Q, Peng Y, Eckenhoff MF, Wei H: Dantrolene ameliorates cognitive decline and neuropathology in Alzheimer triple transgenic mice. Neurosci Lett 2012, 516:274-279.

135. Chakroborty S, Briggs C, Miller MB, Goussakov I, Schneider C, Kim J, Wicks J, Richardson JC, Conklin V, Cameransi BG, Stutzmann GE: Stabilizing ER Ca2+ channel function as an early preventative strategy for Alzheimer's disease. PLoS One 2012, 7:e52056.

136. Popescu BO, Oprica M, Sajin M, Stanciu CL, Bajenaru O, Predescu A, Vidulescu C, Popescu LM: Dantrolene protects neurons against kainic acid induced apoptosis in vitro and in vivo. J Cell Mol Med 2002, 6:555-569.

137. Wei H, Perry DC: Dantrolene is cytoprotective in two models of neuronal cell death. J Neurochem 1996, 67:2390-2398.

138. Nakayama R, Yano T, Ushijima K, Abe E, Terasaki H: Effects of dantrolene on extracellular glutamate concentration and neuronal death in the rat hippocampal CA1 region subjected to transient ischemia. Anesthesiology 2002, 96:705-710

139. Chen X, Wu J, Lvovskaya S, Herndon E, Supnet C, Bezprozvanny I: Dantrolene is neuroprotective in Huntington's disease transgenic mouse model. Mol Neurodegener 2011, 6:81.

140. Suzuki M, Nagai $Y$, Wada K, Koike T: Calcium leak through ryanodine receptor is involved in neuronal death induced by mutant huntingtin. Biochem Biophys Res Commun 2012, 429:18-23.

141. Chen X, Tang TS, Tu H, Nelson O, Pook M, Hammer R, Nukina N, Bezprozvanny I: Deranged calcium signaling and neurodegeneration in spinocerebellar ataxia type 3. J Neurosci 2008, 28:12713-12724.

142. Liu J, Tang TS, Tu H, Nelson O, Herndon E, Huynh DP, Pulst SM, Bezprozvanny I: Deranged calcium signaling and neurodegeneration in spinocerebellar ataxia type 2. J Neurosci 2009, 29:9148-9162.

143. Frandsen A, Schousboe A: Dantrolene prevents glutamate cytotoxicity and $\mathrm{Ca} 2+$ release from intracellular stores in cultured cerebral cortical neurons. J Neurochem 1991, 56:1075-1078.

144. Bouchelouche P, Belhage B, Frandsen A, Drejer J, Schousboe A: Glutamate receptor activation in cultured cerebellar granule cells increases cytosolic free Ca2+ by mobilization of cellular Ca2+ and activation of Ca2+ influx. Exp Brain Res 1989, 76:281-291.

145. Guo Q, Sopher BL, Furukawa K, Pham DG, Robinson N, Martin GM, Mattson MP: Alzheimer's presenilin mutation sensitizes neural cells to apoptosis induced by trophic factor withdrawal and amyloid beta-peptide: involvement of calcium and oxyradicals. J Neurosci 1997, 17:4212-4222

146. Imaizumi K, Morihara T, Mori Y, Katayama T, Tsuda M, Furuyama T, Wanaka A, Takeda M, Tohyama M: The cell death-promoting gene DP5, which interacts with the BCL2 family, is induced during neuronal apoptosis following exposure to amyloid beta protein. J Biol Chem 1999 274:7975-7981.

147. Supnet C, Noonan C, Richard K, Bradley J, Mayne M: Up-regulation of the type 3 ryanodine receptor is neuroprotective in the TgCRND8 mouse model of Alzheimer's disease. J Neurochem 2010, 112:356-365.

148. Ghosh A, Greenberg ME: Calcium signaling in neurons: molecular mechanisms and cellular consequences. Science 1995, 268:239-247.

149. Trinchese F, Fa M, Liu S, Zhang H, Hidalgo A, Schmidt SD, Yamaguchi H, Yoshii N, Mathews PM, Nixon RA, Arancio O: Inhibition of calpains improves memory and synaptic transmission in a mouse model of Alzheimer disease. J Clin Invest 2008, 118:2796-2807.

150. Grynspan F, Griffin WR, Cataldo A, Katayama S, Nixon RA: Active sitedirected antibodies identify calpain II as an early-appearing and pervasive component of neurofibrillary pathology in Alzheimer's disease. Brain Res 1997, 763:145-158.

151. Wang HG, Pathan N, Ethell IM, Krajewski S, Yamaguchi Y, Shibasaki F, McKeon F, Bobo T, Franke TF, Reed JC: Ca2 + -induced apoptosis through calcineurin dephosphorylation of BAD. Science 1999, 284:339-343.
152. Dineley KT, Hogan D, Zhang WR, Taglialatela G: Acute inhibition of calcineurin restores associative learning and memory in Tg2576 APP transgenic mice. Neurobiol Learn Mem 2007, 88:217-224.

153. Cardoso SM, Oliveira CR: The role of calcineurin in amyloid-beta-peptidesmediated cell death. Brain Res 2005, 1050:1-7

154. Malenka RC, Bear MF: LTP and LTD: an embarrassment of riches. Neuron 2004, 44:5-21

155. Bardo S, Cavazzini MG, Emptage N: The role of the endoplasmic reticulum $\mathrm{Ca} 2+$ store in the plasticity of central neurons. Trends Pharmacol Sci 2006, 27:78-84.

156. Bouchard R, Pattarini R, Geiger JD: Presence and functional significance of presynaptic ryanodine receptors. Prog Neurobiol 2003, 69:391-418.

157. Zucker RS, Regehr WG: Short-term synaptic plasticity. Annu Rev Physiol 2002, 64:355-405.

158. Yuste R, Majewska A, Holthoff K: From form to function: calcium compartmentalization in dendritic spines. Nat Neurosci 2000, 3:653-659.

159. Raymond CR, Redman SJ: Spatial segregation of neuronal calcium signals encodes different forms of LTP in rat hippocampus. J Physiol 2006, 570:97-111.

160. Obenaus A, Mody I, Baimbridge KG: Dantrolene-Na (Dantrium) blocks induction of long-term potentiation in hippocampal slices. Neurosci Lett 1989, 98:172-178.

161. Harvey J, Collingridge GL: Thapsigargin blocks the induction of long-term potentiation in rat hippocampal slices. Neurosci Lett 1992, 139:197-200

162. Nishiyama M, Hong K, Mikoshiba K, Poo MM, Kato K: Calcium stores regulate the polarity and input specificity of synaptic modification. Nature 2000, 408:584-588.

163. Fitzjohn SM, Collingridge GL: Calcium stores and synaptic plasticity. Cell Calcium 2002, 32:405-411.

164. Shimuta M, Yoshikawa M, Fukaya M, Watanabe M, Takeshima H, Manabe T: Postsynaptic modulation of AMPA receptor-mediated synaptic responses and LTP by the type 3 ryanodine receptor. Mol Cell Neurosci 2001, 17:921-930.

165. Futatsugi A, Kato K, Ogura H, Li ST, Nagata E, Kuwajima G, Tanaka K, Itohara S, Mikoshiba K: Facilitation of NMDAR-independent LTP and spatial learning in mutant mice lacking ryanodine receptor type 3. Neuron 1999, 24:701-713.

166. Stutzmann GE, LaFerla FM, Parker I: Ca2+ signaling in mouse cortical neurons studied by two-photon imaging and photoreleased inositol triphosphate. J Neurosci 2003, 23:758-765.

167. Chakroborty S, Stutzmann GE: Early calcium dysregulation in Alzheimer's disease: setting the stage for synaptic dysfunction. Sci China Life Sci 2011, 54:752-762

168. Chakroborty S, Kim J, Schneider C, Jacobson C, Molgo J, Stutzmann GE: Early presynaptic and postsynaptic calcium signaling abnormalities mask underlying synaptic depression in presymptomatic Alzheimer's disease mice. J Neurosci 2012, 32:8341-8353.

169. Ziviani E, Lippi G, Bano D, Munarriz E, Guiducci S, Zoli M, Young KW, Nicotera P: Ryanodine receptor-2 upregulation and nicotine-mediated plasticity. EMBO J 2011, 30:194-204

170. Zhao W, Meiri N, Xu H, Cavallaro S, Quattrone A, Zhang L, Alkon DL: Spatial learning induced changes in expression of the ryanodine type II receptor in the rat hippocampus. FASEB J 2000, 14:290-300.

171. Matsuo N, Tanda K, Nakanishi K, Yamasaki N, Toyama K, Takao K, Takeshima $\mathrm{H}$, Miyakawa T: Comprehensive behavioral phenotyping of ryanodine receptor type 3 (RyR3) knockout mice: decreased social contact duration in two social interaction tests. Front Behav Neurosci 2009, 3:3.

172. Alkon DL, Nelson TJ, Zhao W, Cavallaro S: Time domains of neuronal Ca2+ signaling and associative memory: steps through a calexcitin, ryanodine receptor, K + channel cascade. Trends Neurosci 1998, 21:529-537.

173. Elias GM, Elias LA, Apostolides PF, Kriegstein AR, Nicoll RA: Differential trafficking of AMPA and NMDA receptors by SAP102 and PSD-95 underlies synapse development. Proc Natl Acad Sci U S A 2008, 105:20953-20958.

174. Tollefson GD: Short-term effects of the calcium channel blocker nimodipine (Bay-e-9736) in the management of primary degenerative dementia. Biol Psychiatry 1990, 27:1133-1142.

175. Bullock R: Efficacy and safety of memantine in moderate-to-severe Alzheimer disease: the evidence to date. Alzheimer Dis Assoc Disord 2006, 20:23-29.

doi:10.1186/1750-1326-9-21

Cite this article as: Del Prete et al:: Ryanodine receptors: physiological

function and deregulation in Alzheimer disease. Molecular

Neurodegeneration 2014 9:21. 